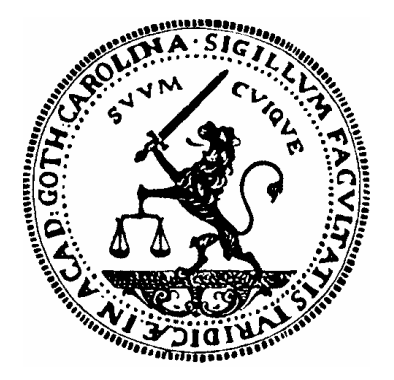

FACULTY OF LAW

University of Lund

Christine Lagström

\title{
The Disappeared Children of El Salvador - a field study of truth, justice and reparation
}

Master thesis

20 points

Ineta Ziemele

Public International Law

Human Rights

Spring 2005 


\section{Contents}

$\begin{array}{ll}\text { SUMMARY } & 4\end{array}$

$\begin{array}{ll}\text { PREFACE } & 5\end{array}$

$\begin{array}{ll}\text { ABBREVIATIONS } & 6\end{array}$

1 INTRODUCTION

1.1 Purpose 9

1.2 Method and material 9

$\begin{array}{ll}1.3 \text { Delimitations } & 10\end{array}$

$\begin{array}{lll}1.4 & \text { Disposition } & 10\end{array}$

2 BRIEF POLITICAL HISTORY OF EL SALVADOR 12

2.1 Post-colonialism and $2000^{\text {th }}$ century 12

2.2 Civil war: violence and politics 13

$\begin{array}{ll}2.3 & \text { The UN peace negotiations } \\ 2.4\end{array}$

2.4 Implementing the Peace Accords 17

2.5 Recent political development 20

3 ENFORCED DISAPPEARANCES OF CHILDREN 21

3.1 A strategy of the government forces 21

3.2 Two illustrative cases 23

3.3 What happened to the children? 23

3.4 The NGO "Pro-Búsqueda” 25

4 SITUATION OF THE VICTIMS AT THE NATIONAL LEVEL 27

4.1 The Truth Commission - from madness to hope 27

4.2 Amnesty laws and impunity 29

$\begin{array}{lll}4.3 & \text { Politics of negation } & 32\end{array}$

4.4 PDDH and the disappeared children 33

$\begin{array}{lll}4.5 & \text { Habeas corpus } & 34\end{array}$

4.6 Creation of a national search commission? 35

4.6.1 The efforts of Pro-Búsqueda 35

$\begin{array}{lll}\text { 4.6.2 The PDDH } & 37\end{array}$

4.6.3 An Inter-institutional Commission 37

4.7 National monument 38

4.8 What remedy do the victims want? 39

5 THE SERRANO CRUZ CASE AND THE INTER-AMERICAN SYSTEM $\quad 40$

5.1 The Serrano Cruz case - background 40

5.2 The legal process in El Salvador 41 
5.3 The IACHR 42

5.4 The Salvadoran legal actions after 1999

5.5 The Inter-American Court 44

5.6 Consequences of the Serrano Cruz case 46

6 INTERNATIONAL AND REGIONAL HUMAN RIGHTS LAW 47

6.1 Right to an effective remedy and reparation 47

6.2 The state's obligations $\quad 49$

6.2.1 The obligation to guarantee human rights 49

6.2.2 The obligation to provide an effective remedy 52

6.3 Enforced disappearances 53

6.3.1 In general 53

6.3.2 Enforced disappearance of minors 55

6.3.3 The victims 56

6.3.4 Enforced disapperances and state obligations 56

6.3.4.1 The ICCPR 56

6.3.4.2 The ACHR 58

6.4 The legality of amnesty laws under human rights law 59

$\begin{array}{ll}\text { 6.4.1 The position of of the HRC } & 59\end{array}$

6.4.2 The position of the Inter-American System 60

7 ANALYSIS AND CONCLUSIONS 62

7.1 Obligations of El Salvador 62

7.2 Is El Salvador in breach of its obligations? 65

7.3 Why does El Salvador not comply with international law? 66

7.4 Will the victims obtain truth, justice and reparation? 69

$\begin{array}{lll}7.5 & \text { Conclusions } & 70\end{array}$

$\begin{array}{ll}\text { SUPPLEMENT A } & 73\end{array}$

$\begin{array}{ll}\text { SUPPLEMENT B } & 75\end{array}$

$\begin{array}{ll}\text { BIBLIOGRAPHY } & 76\end{array}$

$\begin{array}{ll}\text { TABLE OF CASES } & 80\end{array}$ 


\section{Summary}

During the Salvadoran armed conflict (1980-1992) hundreds of children became separated from their families. The majority of the children were abducted by the armed forces of the government and still to this day the fate and whereabouts of most children are unknown. These children are the "disappeared children of El Salvador". In 1994, families of the disappeared children formed an organisation, Pro-Búsqueda, which above all tries to locate the children. Investigations done by Pro-Búsqueda show that some of the children were given up for adoption and others grew up at institutions.

When human rights violations occur, such as the enforced disappearance of minors, the state has certain obligations according to international and regional human rights law. From the general obligations of states to guarantee human rights and to provide victims with an effective remedy it can be concluded that the victims of the enforced disappearance of minors, which includes both the children and their families, should be afforded truth, justice and reparation. In this specific case what constitutes fair reparation is compensation for the pain and suffering, measures of rehabilitation and satisfaction, such as a public apology. Even in those cases where children were abducted by non-state agents, the Salvadoran state has an obligation to provide for access to truth, justice and reparation.

The Salvadoran government has not adequately dealt with redressing the victims of the enforced disappearance of children. Instead, the politics of negation and impunity have been strong in El Salvador. This constitutes a breach of the obligations mentioned above, for which El Salvador can be held internationally responsible. The Inter-American has judged on the question of state responsibility in the Serrano Cruz case. However, this case does not have direct implications for the victims at the national level, except for putting pressure on the state to comply with international law.

In order to justify the politics of negation the Salvadoran government claims that national reconciliation only can be achieved through "forgiving and forgetting" the past. The main reason for holding on to the politics of negation is that most of the disappeared children were abducted by organs acting on behalf of the state and recognising the rights of the victims could lead to stronger demands of prosecuting those responsible.

As for the prospects of the victims to obtain truth, justice and reparation it can be concluded that a change in the Salvadoran government's attitude seems far away. The Serrano Cruz case could put some pressure on the state to act in accordance with international human rights law, but at the time of writing this thesis there are indications that it will not take much influence of the judgment. However, if the efforts of the civil society and the international community to bring on a change persist, it could lead to that the Salvadoran will take on its responsibilities in the future. 


\section{Preface}

First of all I would like to express my gratitude to Sida and the Raoul Wallenberg Institute of Human Rights and Humanitarian Law for giving me the opportunity to go to El Salvador to conduct a minor field study. Especially I would like to thank Andreas Ljungholm for encouraging me to apply for the scholarship and Abigail Booth who put me in contact with my Salvadoran supervisor.

I would like to thank my supervisor Ineta Ziemele for her guidance and advice while writing this thesis.

My gratitude goes to licenciado Hugo Figueroa, my supervisor at la Universidad Nacional de El Salvador, who gave me a lot of support in the field. I would also like to thank all the kind persons I met at the UES, especially Patricia Dubón and Nelson Mejía, for making my stay in San Salvador pleasant.

Lastly, I must thank my mother and Martin for always believing in me and supporting me. The same goes for my friends in Sweden and El Salvador. Thank you Kelly for being such a good friend and showing me your country. 


\section{Abbreviations}

\begin{tabular}{|c|c|}
\hline ACHR & American Convention on Human Rights \\
\hline ARENA & Alianza Republicana Nacionalista \\
\hline CIA & Central Intelligence Agency \\
\hline CD & Convergencia Democrática \\
\hline CDHES & Comisión de Derechos Humanos de El Salvador \\
\hline CEJIL & Centro por la Justicia y el Derecho Internacional \\
\hline CNB & $\begin{array}{l}\text { Comisión Nacional de Búsqueda de Niñas y } \\
\text { Niños Desaparecidos de El Salvador }\end{array}$ \\
\hline CODEFAM & $\begin{array}{l}\text { El Comité de Familiares de Víctimas de } \\
\text { Violaciones a los Derechos Humanos }\end{array}$ \\
\hline COPAZ & $\begin{array}{l}\text { Comisión Nacional para la Consolidación de la } \\
\text { Paz }\end{array}$ \\
\hline $\mathrm{CPDH}$ & $\begin{array}{l}\text { Centro para la Promoción de los Derechos } \\
\text { Humanos }\end{array}$ \\
\hline FMLN & $\begin{array}{l}\text { Frente Farabundo Martí para la Liberación } \\
\text { Nacional }\end{array}$ \\
\hline GA & General Assembly (of the UN) \\
\hline HRC & Human Rights Committee \\
\hline IACHR & Inter-American Commission on Human Rights \\
\hline ICCPR & $\begin{array}{l}\text { International Covenant on Civil and Political } \\
\text { Rights }\end{array}$ \\
\hline IDHUCA & $\begin{array}{l}\text { Instituto de Derechos Humanos de la Universi- } \\
\text { dad Centroamericana "José Simeón Cañas" }\end{array}$ \\
\hline NGO & Non Governmental Organisation \\
\hline OAS & Organisation of American States \\
\hline ONUCA & $\begin{array}{l}\text { United Nations Observer Group in Central } \\
\text { America }\end{array}$ \\
\hline ONUSAL & United Nations Observer Group in El Salvador \\
\hline PCN & Partido de Conciliación Nacional \\
\hline PDC & Partido Demócrata Cristiano \\
\hline PDDH & $\begin{array}{l}\text { Procuraduría para la Defensa de los Derechos } \\
\text { Humanos }\end{array}$ \\
\hline PNC & Policía Nacional Civil \\
\hline SG & Secretary General (of the UN) \\
\hline STC & Salvadoran Truth Commission \\
\hline UN & United Nations \\
\hline US & United States (of America) \\
\hline
\end{tabular}




\section{Introduction}

The subject of this master thesis is the victims' right to an effective remedy and reparation for crimes against international human rights law committed during the armed conflict in El Salvador and the state's obligation to provide for this. In many post-conflict and transitional societies impunity prevails. Impunity is the term for the phenomenon where states fail to meet their obligations to investigate violations, to take appropriate measures in respect of perpetrators and this unwillingness to deal with past human rights violations leads to the fact that victims are not provided with effective remedies and reparation for the injuries suffered. It is a fact that once state authorities fail to investigate the facts and to establish criminal responsibility, it becomes difficult for victims or their relatives to carry on effective legal proceedings aimed at obtaining just and adequate reparation. The topic of impunity and post-conflict justice has been increasingly dealt with in the scholarly debate. However, the focus has mainly been put on individual criminal liability, so called "retributive" justice. The recent development in the field of international criminal law and the creation of the International Criminal Court has inspired these discussions.

This study concentrates on the process of "reparative" or "restorative" justice at the national level. This sort of justice refers to efforts to acknowledge and repair the harm and pain of victims, even though nothing can ever fully repair the damage done to victims, or more specific alleviate the suffering of a parent who has lost a child. Perhaps the most important goals of this process are the "re-humanisation" of the victims and their restoration as functioning members of society. Achieving these restorative goals is fundamental to both the peace and security of any state since it eliminates the potential of future revenge. In other words, providing victims with reparation is important to reconcile a post-conflict society. What makes the issue of victim's remedy for human rights violations problematic is that there traditionally are two tendencies in post-war societies: for one part, the civil society movement of human rights which demands truth, justice and reparation and, for the other part, the official politics of negation and impunity which insists on "forgetting and forgiving" the past. ${ }^{1}$

The country chosen for the study is, as seen above, El Salvador, which is the smallest but most densely populated country in Central America. It still has significant poverty and suffers from frequent natural disasters. Up to 50 per cent of the population lives below the poverty line and the literacy rate is about 80 per cent. The Salvadoran legal system is based on civil and Roman law, with traces of common law and judicial review of legislative acts takes place in the Supreme Court. Since the formal end of the civil war, in January 1992, El Salvador has started to build up its democracy and when it

\footnotetext{
${ }^{1}$ Bassiouni, Cherif M., 'Accountability for Violations of International Humanitarian La and Other Serious Violations of Human Rights', Post-conflict Justice, ed. Bassiouni, 2002, Transantional Publishers: Ardsley N.Y., pp. 37-38
} 
comes to holding free elections El Salvador has succeeded fairly well. What still needs to be improved is the consolidation of the fragile democracy. The rule of law constitutes an important aspect of consolidating democracy and as long as there exists impunity for serious human rights violations the democracy can never be fully consolidated.

Thousands of children became innocent victims during the conflict between the armed forces of the government and the armed guerrilla opposition, FMLN (Frente Farabundo Martí para la Liberación Nacional), in El Salvador. The civil war lasted for more than a decade (1980-1992) and during the first years of the eighties the government forces practised the strategy of "enforced disappearances of minors". Children were either separated and abducted from their families or taken by the army soldiers after their parents had been murdered during army attacks on their villages. Some children were brought to orphanages or other institutions and others were held at military bases or kept in the houses of the soldiers and their families. Some of the children were given up for adoption, either within the country or abroad. To a much lesser extent children were separated from their parents by the FMLN. However, this can not be said to have been a deliberate strategy, as was the case with the practices of the armed forces.

Even though enforced disappearances have occurred systematically for more than 30 years, there is no universal human rights treaty that contains a specific right to be protected against enforced disappearance. It is generally considered as a multiple human rights violation and the concept of enforced disappearances and the standards of protection have been developed by various human rights monitoring bodies and courts. The fact that children systematically were the victims of disappearances during the Salvadoran armed conflict distinguishes it from "ordinary" cases of enforced disappearances. Above all, the children's right to their identity has been affected through the abduction and subsequent happenings.

For obvious reasons grave and systematic violations of human rights are irreparable. There can not be any proportional relationship between the reparation and the injury inflicted upon the victims. It is, nevertheless, an imperative of justice that responsibility of perpetrators should be established and that attention be given to the victims in terms of reparation. Notwithstanding the widespread abuses of recent history, few efforts have been undertaken to provide redress to the victims and their families. This is the result of the fact that either the violator regime or a successor government often have treated post-conflict justice as a bargaining chip used in negotiations rather than an affirmative duty. Many national authorities consider the victims' perspective an inconvenience and consequently ignore their rights in favour of the politics of impunity. Despite the fact that the victims' right to a remedy and reparation in most cases has been neglected on the national level, it is becoming increasingly important in the case law of international human rights bodies as well as through the efforts to draft 
guidelines on the right to remedy and reparation, which aims at providing a framework that ensures the redress of violations of human rights. ${ }^{2}$

\subsection{Purpose}

The overall purpose of this study is to examine the problems of establishing truth, achieving justice and affording reparation to the victims of the disappearance of children and to see how this category of victims has been treated by the Salvadoran authorities. The first question is what obligations, according to international and regional human rights law, El Salvador has to comply with when a human rights violation has occurred, such as the enforced disappearance of a child. Has El Salvador acted in breach of these obligations and what might the consequences of a breach be? Thirdly, why does El Salvador not comply with international law? Finally, what are the prospects to overcome the Salvadoran impunity for past human rights violations? Will the case before the Inter-American Court regarding two disappeared Salvadoran sisters affect the situation at the national level?

\subsection{Method and material}

This master thesis has been carried through as a Minor Field Study conducted during approximately two months in the capital of El Salvador, San Salvador. It has been financed through a scholarship obtained from Sida, the Swedish Development Cooperation Agency. The reason for doing a field study was to be able to gather the material required for completing the thesis. In San Salvador I have been conducting interviews with persons representing various institutions and organisations, both governmental and non-governmental, which are involved in the questions of impunity, human rights and victim reparation. I have also gathered written material, such as reports and resolutions on the question of disappeared children, which are not available in Sweden. I also attended a seminar at La Universidad Centroamericana, regarding the issue of victims and justice.

Besides the material gathered in field, I have used written material regarding international human rights law, reports from Amnesty International concerning the disappeared children, concluding observations and decisions on individual petitions by the Human Rights Committee (HRC), reports of the Inter-American Commission on Human Rights (IACHR) and judgments and advisory opinions of the Inter-American Court. I have used legal sources at the national level, such as the amnesty law of 1993. The UN Truth Commission and its report are examined in order to see if it has contributed to the truth, justice and reparation regarding the disappeared

\footnotetext{
${ }^{2}$ Boven, Theo van, Study Concerning the Right to Restitution, Compensation and Rehabilitation for Victims of Gross Violations of Human Rights and Fundamental Freedoms, 2 July 1993, E/CN.4/SUB.2/1993/8, p. 341-342
} 
children. Furthermore, material from the NGO Pro-Búsqueda and resolutions from the Human Rights Ombudsman have been examined.

International human rights conventions of interest for this study, and to which El Salvador is a state party, are the International Covenant on Civil and Political Rights (ICCPR) and the American Convention on Human Rights (ACHR). However, El Salvador has not ratified, or even signed, the Inter-American Convention on Forced Disappearance of Persons.

In order to be able to draw conclusions from this study, I will apply standards of international law on the factual situation in El Salvador regarding the victims' right to remedy and reparation and the state's corresponding obligations.

\subsection{Delimitations}

Since human rights that are codified in international treaties are to be protected first and foremost by the relevant national legal protection institutions, the study will mainly be concentrated on the national level; in this case the focus is on the processes in El Salvador. I will however, to some extent, examine the regional mechanism of the Inter-American System of Human Rights, which is important in the case of disappeared children, since the Inter-American Court has accepted a case concerning two abducted children from El Salvador. I have limited the scope of this study to one specific category of victims - those who are affected by the disappearances of children. This enables me to look closer at the issue of the victims' right to an effective remedy and reparation.

Regarding international law, I have chosen to limit the scope of this study to only take the provisions of the ICCPR and the ACHR into account, as interpreted by the HRC, the IACHR and the Inter-American Court of Human Rights. This delimitation is done since these general treaties, to which El Salvador is a state party, contain provisions regarding effective remedy, which is of concern for this study. International humanitarian law standards, especially protocol II of the Geneva Conventions, apply in civil war situations, but there does not seem to exist a clear nexus between a breach of these standards and the victims' right to remedy and reparation. Therefore I will not take international humanitarian law into account since it does not have any added value regarding the victims right to truth, justice and reparation.

\subsection{Disposition}

The disposition of this thesis will be as follows. In order to get a picture of the situation in El Salvador, I will start with a chapter containing a brief description of the country's political history, putting emphasis on the civil 
war and the peace negotiations. The subsequent chapter deals with the topic of disappeared children. Here the general patterns of the disappearances and the work of the NGO "Asociación Pro-Búsqueda de Niñas y Niños Desaparecidos” are described. Chapter 4 deals with the victims' access to remedies at the national level. The situation for the victims of the enforced disappearance of children, concerning truth, justice and reparation, is dealt with. The next chapter concerns the Serrano Cruz case and how this case has been handled by the Inter-American System of Human Rights and by national judicial authorities. Chapter 6 puts light on the relevant international and regional law standards on human rights. Finally, chapter 7 contains the analysis which leads to the conclusions that can be drawn from applying the international law on the Salvadoran situation. 


\section{Brief political history of EI Salvador}

\subsection{Post-colonialism and $2000^{\text {th }}$ century}

The history of El Salvador revolves around one central issue - land. El Salvador is the smallest but by far the most densely populated country in Central America. Land has always been a scarce commodity whose importance has been amplified by the comparative absence of metals or mineral deposits. Unequal distribution of the land has been a historical fact that can be traced to the Spanish colonial system. El Salvador gained independence from Spain 1821, but that did not change the dynamics of land ownership. In 1841, following the dissolution of the Central American Federation, El Salvador became a sovereign independent nation.

During the first decades of the $20^{\text {th }}$ century efforts by the poor majority to redress El Salvador's social and economic injustices were met with severe repression. In January 1932, Farabundo Martí, a founder of the Central American Socialist Party, led an uprising of peasants and Indians. The military responded by systematically killing those who supported the uprising. Approximately 30,000 persons were killed. From that point, the military became institutionalised and independent from the oligarchy and proceeded to assume control over the political process in El Salvador.

During the 1960's El Salvador's failing economy in combination with overpopulation drove hundreds of thousands of Salvadorans to illegally cross the border to Honduras. In 1969 El Salvador accused Honduras of mistreatment of Salvadoran immigrants and this happened when qualifying matches for the soccer World Cup were being played between the two countries. National rivalries escalated and resulted in a Salvadoran invasion of Honduran territory. The conflict, popularly called the "soccer war", lasted less than 100 hours and took about 6,000 lives.

During the 1970's the population suffered from increased landlessness, poverty and unemployment. Political parties became more polarised and fought for power largely through coups and electoral fraud. In 1972 the military arrested and exiled the elected president and installed their own candidate in power. Guerrilla activity increased and the government responded through so called "death squads", who murdered, tortured or kidnapped thousands of people. ${ }^{3}$

\footnotetext{
${ }^{3}$ Political history of El Salvador from 2000 BC until today, http://wrc.lingnet.org/ elsalhis.htm, 2004-09-09
} 
Towards the end of the 1970's there were talks of reform, but it was replaced by an escalating campaign of repression and political killing. The victory of the Nicaraguan revolutionaries in July 1979 triggered a military junta to stage a coup against the president, since they wanted to avoid a repetition of the Nicaraguan experience in El Salvador. The junta stated its intention to restore the rule of law and create a climate of peace, but unhappily, this initial promise to prevent the slide into war was not realised. ${ }^{4}$

\subsection{Civil war: violence and politics}

Instead of leading to peace, the 1979 coup led to a surge in repression and public insecurity and to a climate in which paramilitary forces and other armed groups increasingly were engaging in terrorism and violence with impunity. During this time various guerrilla groups had been moving toward greater unity. In October 1980, FMLN, was established. In order to oppress the guerrilla movement, the Salvadoran government, like many other Latin American governments, applied the doctrine of national security. This doctrine was formed in the US as a response to the cold war and at the national level the doctrine was based on three basic guidelines: preventive war, counter-insurgency war against the guerrilla movements (like in El Salvador) and counter-revolutionary war. The enemy was considered to be inside of the country, not outside. ${ }^{5}$ There was considerable foreign involvement in the conflict, reflecting the ongoing cold war. The US supported the Salvadoran government with military training, weapons and financial aid, despite concern over human rights violations. The FMLN, for its part, was backed by their ideological allies Cuba, Nicaragua and the Soviet Union.

There is wide agreement that the root causes of the conflict were twofold the power of the armed forces and the depth of social injustice. The move toward open warfare between the government forces and the guerrilla forces was accelerated by the assassination of Archbishop Romero, who promoted social reform, as he was saying mass 24 March 1980. In the armed struggle that went on for more than a decade, it is estimated that more than 75,000 persons were tortured, subjected to extrajudicial killings, or simply disappeared. ${ }^{6}$ Of those directly victimised by the war, the largest number were people who had to flee from their homes to take refuge either outside or inside the country. At least one fourth of the entire population became refugees or internally displaced. ${ }^{7}$

\footnotetext{
${ }^{4}$ Human Rights Watch: El Salvador's Decade of Terror, 1991, p. 7

${ }^{5}$ Public hearing at the Committee of Foreign Affairs, Security and Defence Policy, Subcommittee on Human Rights, Brussels 30-31 October 1996, Impunity in Latin America by Luis Carlos Nieto, http://www.europarl.eu.int/hearings/impunity/latinam3 en.htm, 2004-09-10

${ }^{6}$ The United Nations and El Salvador, The United Nations Blue Book Series, Volume IV, pp. 6-7

Human Rights Watch: El Salvador's Decade of Terror, 1991, p. 107
} 
The most violent years were the first years of the 1980's. FMLN guerrillas gained control of areas in the north and east of El Salvador and blew up bridges, destroyed power lines and burned coffee plantations in a bid to crush the country's economy. The FMLN was also responsible for murder and violence, assassinating mayors and judges. Violence attributed to the government was primarily directed against civilians in guerrilla friendly zones and included arbitrary detention, enforced disappearances, death squad killings and various massacres of villages. ${ }^{8}$

In 1982 El Salvador held elections for a constituent assembly, which was assigned with the task to produce a new constitution. ${ }^{9}$ The right-wing party "Alianza Republicana Nacionalista" (ARENA), in coalition with the traditional military-based "Partido de Conciliación Nacional" (PCN), named the extremist D'Aubuisson president of the lawmaking body. The left did not participate in the election, at least in part out of fear. In 1984 presidential election was held and it seemed to be free from fraud, although there were allegations that the CIA of the US heavily financed the campaign of the winner, Duarte of the "Partido Demócrata Cristiano" (PDC). As in the 1982 elections, the left-wing parties, concerned about the safety of their candidates and supporters, did not participate. ${ }^{10}$

Towards the end of 1984 president Duarte intended to initiate peace talks with the FMLN, but the positions of the government and the guerrillas appeared to be irreconcilable. President Duarte reportedly proposed that the FMLN lay down its weapons under a guarantee of amnesty and become a political party competing in elections. The guerrillas, for their part, demanded participation in a provisional government that would arrange new elections and reorganise the military. The talks broke down and were not continued for several years when the UN Peace negotiations started. ${ }^{11}$

In August 1987 the presidents of five Central American countries signed the so called Esquipulas II Agreement about the "Procedure for the Establishment of a Firm and Lasting Peace in Central America". Some have called this agreement the official birth of the peace process and the presidents undertook to initiate a process of democratisation, promote a national dialogue, decree a general amnesty, establish a genuine cease-fire and promote free, pluralistic and fair elections. ${ }^{12}$ The Esquipulas II Agreement brought about an important political opening in El Salvador, allowing civilian politicians allied with the FMLN to return and making their subsequent participation in the 1989 presidential elections possible. Although left-wing leaders formed a new Democratic Convergence (CD), they did not participate in the 1988 legislative and municipal elections. This was because several leaders were threatened and the structures of their political parties could not be quickly rebuilt after years of repression. When

\footnotetext{
${ }^{8}$ The United Nations and El Salvador, 1995, p. 8

${ }^{9}$ The Constitution of 1983 is still in force, but it has been reformed after the war.

${ }^{10}$ Human Rights Watch: El Salvador's Decade of Terror, 1991, p. 11

11 ibid., p. 12

12 The United Nations and El Salvador, 1995, p. 9
} 
it drew closer to the 1989 presidential elections the FMLN, wanting to participate, proposed that they would respect the results provided that the elections were postponed six months. The government and the guerrilla failed to agree on the proposal and the elections went ahead as scheduled. Even though the FMLN did not participate, the CD did, making this the first elections since 1977 in which any party of the left had appeared on the ballot. The CD only received 3,8 per cent of the vote, maybe because the guerrillas discouraged voting. Instead, the ARENA-candidate Cristiani won a convincing victory. The ARENA government had to confront a major challenge in the end of 1989 when FMLN launched an urban offensive that seemed to threaten the military's hold on the capital and the fighting went on for three weeks. The offensive failed to provoke the broad insurrection that the guerrilla hoped for, illustrating the limit of their popular support. ${ }^{13}$

\subsection{The UN peace negotiations}

The UN first became involved in the situation in December 1980, when the General Assembly (GA) adopted a resolution in which it condemned the "murders, disappearances and other violations of human rights reported in El Salvador" and urged the Salvadoran government to "take the necessary steps to ensure full respect for human rights and fundamental freedoms in that country". ${ }^{14}$ The UN got more directly involved in the El Salvador conflict after the signing of the Esquipulas II Agreement since it, as a step of international verification, established an on-site mechanism, the United Nations Observer Group in Central America (ONUCA).

In September 1989 the Salvadoran government and FMLN agreed to start a dialogue aimed at ending the conflict by political means. The Secretary General (SG) of the UN was invited to talks that were scheduled to October 1989. However, no substantial negotiation could be held since the position of the both parties was locked. The negotiations were finally broken off by the FMLN in response to a bombing directed against a union hall and after that FMLN launched its large urban offensive. In December 1989 and January 1990, the FMLN and president Cristiani separately requested the SG to assist them in their efforts to settle the conflict. From this point on the UN acted as a catalyst for peace and a framework for the negotiations was established, to which both parties agreed. ${ }^{15}$

The San José Agreement, signed 26 July 1990, was the first substantive agreement between the government and the FMLN. The agreement put emphasis on the respect for international human rights standards and under it a UN verification mission (ONUSAL) would be established. This mission would have the power to receive communications about human rights violations, freely conduct interviews with whom they wanted, conduct on-

\footnotetext{
${ }^{13}$ Human Rights Watch: El Salvador's Decade of Terror, 1991, pp. 14-15

${ }^{14}$ General Assembly Resolution 35/192

${ }^{15}$ The United Nations and El Salvador, 1995, pp. 11-12
} 
site visits without prior notice, carry out an educational and informational campaign on human rights and lastly to take action to promote and defend human rights. The San José Agreement stated that the mission would start working in the country after the cessation of the armed conflict but both parties asked the UN to establish the mission as soon as possible, even before cease-fire. ${ }^{16}$ (Read more about ONUSAL chapter 2.4).

The next step for the negotiators was to try to broaden the San José achievements. 27 April 1991, the parties agreed on some issues essential for peace. This agreement concerned reforms relating to the armed forces, public security, the judicial system and the electoral system and it established that a truth commission should be formed. In order to incorporate any peace agreements into the Salvadoran legal order, the constitution would have to be amended. The legislative assembly approved nearly all of the constitutional alterations, but reforms related to the armed forces were left pending. ${ }^{17}$

After the agreement of April 1991, the government and the FMLN held several meetings without making significant progress. FMLN demanded cease-fire arrangements which would allow it to preserve its military capability, while the government could not accept that. To overcome the deadlock, the SG invited president Cristiani and FMLN commanders to the UN headquarters, where matters concerning the armed forces were discussed. The parties decided to create a National Commission for the Consolidation of Peace (COPAZ), to "purify" the armed forces and to reduce its size. However, there was a considerable body of opinion in El Salvador that rejected this agreement and in the absence of a final settlement, the situation remained fragile. The parties were eager to reach a final settlement before the end of the year and at midnight on 31 December 1991 the Act of New York was signed, stating that the final Peace Agreement would be signed on 16 January 1992, that cease-fire would take effect on 1 February 1992 and that the armed conflict would formally end on 31 October 1992. ${ }^{18}$

When it comes to rebuilding a post-conflict society it is important to address the past. The Salvadoran negotiators had the benefit of looking for guidance at the experience of a few other countries, most notably Argentina and Chile. However, the Salvadoran context called for a different approach than in these countries. El Salvador did neither have a defeated nor a wholly discredited military and the country was emerging from a civil war which had resulted in a large number of victims. In addition to the risk that military officers might destabilise the transition process, El Salvador had to assure the participation of FMLN in the political process. The Cristiani government

\footnotetext{
${ }^{16}$ The United Nations and El Salvador, 1995, pp. 13-14

${ }^{17}$ ibid., pp. 15-16

${ }^{18}$ ibid., p. 20-22
} 
did not move towards any measures of truth and justice. The sensitive topic of how to address past abuses was left to the negotiating table. ${ }^{19}$

The negotiations never addressed the need to reach a common understanding to determine the fate and whereabouts of victims, provide reparations and restore the good names of victims. Neither side seemed particularly concerned about protecting the rights of victims. The FMLN decided early on that justice at best would be symbolic and placed greater emphasis on forward-looking reform measures. An FMLN document made exemplary prosecution and punishment in four cases a prerequisite to ceasefire. It noted that after the resolution of these four cases, a broad amnesty would be appropriate. The government, for its part, argued that impunity was not exclusive to the armed forces and should instead be addressed as part of the negotiations on reforming the justice system. The government extended the FMLN's list of cases that ought to be investigated with four cases of violence attributed to the FMLN, but it insisted that the 1987 amnesty law ${ }^{20}$ barred prosecution of all other cases. ${ }^{21}$ As for the final outcome of the negotiations, the San José Accords provided ONUSAL with only a tangential mandate to look at the past. All in all, the peace negotiations resulted only in two measures for addressing past violations of human rights: the Truth Commission and the Ad Hoc Commission. The agreement of establishing the Ad Hoc Commission was reached at the end of the negotiations and it addressed the need to purge the armed forces of those responsible for massive human rights violations. ${ }^{22}$

\subsection{Implementing the Peace Accords}

Relative to other peace processes, the implementation of El Salvador's Peace Accords enjoyed remarkable success. Neither party ever broke the cease-fire. COPAZ was established and served as a mechanism for resolving differences over interpretations and resistance to the fulfilment of the provisions. ${ }^{23}$ ONUSAL began its verification of the San José Agreement in July 1991, nearly six months before the full peace settlement was finalised. The fact that the mission was deployed before a cease-fire was in effect makes it quite unique. ${ }^{24}$ With the signing of the final accord, the function of ONUSAL was expanded to include the verification and monitoring of all the agreements. The human rights division, which already operated in the country, was supplemented by a military and a police division, in order to

\footnotetext{
${ }^{19}$ Popkin, Margaret, Peace without Justice: obstacles to building the rule of law in El Salvador, 2000, pp. 86-89

${ }^{20}$ Ley de Amnistía, Decreto 805, Diario Oficial no. 199, Tomo no. 297, 27 October 1987

${ }^{21}$ Popkin, Margaret, 2000, p. 90

${ }^{22}$ Call, Charles T., 'Democratisation, War and State-Building: Constructing the Rule of Law in El Salvador', Journal of Latin American Studies, 2003, vol. 35, issue 04, Cambridge University Press, p. 835

23 ibid., pp. 833-834

${ }^{24}$ Bar-Yaacov, Nomi, 'The Role of Human Rights in Conflict Resolution in El Salvador and Haiti', Fletcher Forum World Affairs, 1995, vol. 19, p. 51
} 
verify the separation of forces and to monitor the maintenance of public order during the transition period when the National Civil Police (PNC) was being formed. Having such a broad and clear mandate meant that ONUSAL played an indispensable role in the implementation process. ${ }^{25}$

Verifying the peace accords was not an easy task, having the societal polarisation, caused by the conflict years, in mind. The formal cessation of the armed conflict fell behind schedule, there were critical strains concerning land, and ONUSAL staff from time to time received threats. ${ }^{26}$ However, in sum, one can say that ONUSAL's verification in the end had positive results. It has contributed to ending the armed conflict, a decrease in human rights violations and constitutional and legislative reforms which have strengthened democratic institutions. Most observers agree that the transition to peace and democracy in El Salvador has been successful. ${ }^{27}$

In early 1993, the Salvadoran government formally asked the UN to observe the 1994 presidential, legislative and municipal elections. The mandate of ONUSAL was extended and an electoral division was added in order to monitor electoral irregularities. In the elections, the ARENA president candidate, Calderón Sol, won by large, and the ARENA party was also in majority in the legislative assembly. However, the FMLN was established as the second political force in the country. ONUSAL planed for its departure after the elections. Because some parts of the peace accords remained unimplemented the SG proposed that a small team should be left behind. The mandate of this team lasted until April $301996 .^{28}$

Due to the government's massive violations of human rights, the FMLN, during the peace talks, prioritised reforms concerning demilitarisation of internal security and enhancement of human rights protection. The peace agreement contained sweeping military and police reforms and less ambitious, but still important, judicial reforms. Although radical change of the economic structure of the country was a central FMLN objective throughout the war, only about 10 per cent of the final accords dealt with social and economic issues. ${ }^{29}$

Many security reform provisions aimed to transform the repressive and powerful armed forces. Most military leaders, not having been defeated on the battlefield, continued to view FMLN as an illegitimate force and to reject any intrusion by civilians into military affairs. However, after some resistance and delays, the armed forces accepted most institutional changes: the dissolution of the three police forces under its control, the circumscribing of its internal security functions, the dismantling of paramilitary civil defence forces, the suspension of forced recruitment and

\footnotetext{
${ }^{25}$ Call, Charles T., 2003, p. 834

${ }^{26}$ The United Nations and El Salvador, 1995, p. 31

${ }^{27}$ Bar-Yaacov, Nomi, 1995, p. 54

${ }^{28}$ Whitfield, Teresa, 'Staying the Course in El Salvador', Honoring Human Rights, ed. Henkin, Alice H., 2000, Kluwer Law International: The Hague, pp. 320-321

${ }^{29}$ Call, Charles T., 2003, p. 832
} 
the modification of its doctrine and training under an academic council that included civilians of diverse political backgrounds. The military has also considerably reduced its ranks and now it is only one forth of the size it was at the end of the war.

Public security was an important issue when it came to reconstructing the Salvadoran society. The creation of la Policía Nacional Civil (PNC) was crucial for achieving peace and democracy in El Salvador. Since the army refused to accept FMNL troops into its ranks, the agreement to integrate excombatants into the police force was decisive for the peace process. The new doctrine of the police put emphasis on human rights and was under strict civilian leadership. However, the reforms on public security have been made difficult by the post-war crime wave. Unemployment, poverty, disgruntled ex-combatants and a proliferation of guns in the country have led to high homicide rates. This has been the greatest threat against public security and an obstacle for the new police force. ${ }^{30}$

International bodies have decried the weaknesses of the Salvadoran judicial system and its inability to confront grave human rights violations. An independent, efficient, accessible and impartial justice system has not existed in El Salvador. The judicial reforms included new rules for electing judges at all levels, increased the budget of the judiciary, established a human rights ombudsman, gave the attorney general greater responsibility for directing criminal investigations and ended military court jurisdiction over civilians. ${ }^{31}$ Many of the judicial reforms were difficult to implement and one obstacle was the holdover Supreme Court, which remained hostile to the Peace Accords and to ONUSAL throughout its tenure (1989-1994). This meant that the judiciary did not take advantage of ONUSAL's presence in the country and no serious efforts to clean out the judiciary was undertaken. $^{32}$ Finally, in 1994, an entirely new Supreme Court was elected, but the process of replacing incompetent judges in the lower courts, and of strengthening the attorney general's and public defender's offices, has moved more slowly. The government continues to work in all of these areas with the help of international donors.

Another post-war reform is the land transfer reform, which concerned more than 35,000 appropriate beneficiaries from the guerrilla and soldiers who fought the war. The land transfer program, mandated by the peace accords, ended in January 1997. ${ }^{33}$

In much of Latin America, the ombudsman institution has been designed to serve as a key human rights safeguard in the process of restoring or establishing new democratic governments. In a country like El Salvador, where governmental institutions have violated citizens' rights, the potential

\footnotetext{
${ }^{30}$ Call, Charles T., 2003, pp. 835-839

${ }^{31}$ Popkin, Margaret, 2000, p. 101

32 ibid., p. 201

${ }^{33}$ History and politics of El Salvador, http://www.nationmaster.com/encyclopedia/El-

Salvador, 2004-09-20
} 
scope of work for a human rights ombudsman is enormous. An effective ombudsman is likely to clash with governmental authorities. ${ }^{34}$ In El Salvador, la Procuraduría para la Defensa de los Derechos Humanos (PDDH) was mandated by the constitutional reforms of 1991, and it was created to supervise the human rights situation in the country. The PDDH was given the power to investigate cases, give resolutions and make recommendations, and its work is regulated in a special law. ${ }^{35}$

In the beginning the PDDH was slow to assume its responsibilities, determine appropriate priorities and establish necessary credibility and it did not start to work more closely with ONUSAL staff until 1994. Since the establishment of the PDDH, it has shown that progress of the institution to a large extent depends on the will of the person who governs the institution, i.e. the ombudsman him/herself. One of the PDDH's major problems is the lacking of effective follow-up mechanisms to ensure that recommendations are implemented. The Salvadoran entities to which recommendations are directed rarely, if ever, comply with these. However, polls from 1996 and 1998 show that the Salvadorans view the PDDH as the leading institution in defending human rights at the national level. ${ }^{36}$

\subsection{Recent political development}

Regarding the political situation in El Salvador during the last decade, it is accurate to say that great political polarisation remains between the right and left. In December 1992 FMLN became a political party, but they have not, until recently, been able to compete with the leading right-wing party ARENA. However, ARENA's position in the legislative assembly was weakened in the 1997 elections. Internal political differences affected FMLN in the 1999 presidential election and ARENA-candidate Flores became president. In the legislative elections of 2000 and 2003 FMLN defeated ARENA and was, for the first time, in majority in the legislative assembly. ${ }^{37}$ Because of the success of FMLN in the two previous elections, hopes were high that the left-candidate would be elected president in 2004. These hopes were crushed when ARENA's Saca defeated FMLN's Handal. Observers say that the election was fair, but that the campaign before was $\operatorname{dirty}^{38}$

\footnotetext{
${ }^{34}$ Popkin, Margaret, 2000, p. 167

${ }^{35}$ Ley de la Procuraduría para la Defensa de los Derechos Humanos, decreto no. 183, Diario Oficial no. 45, Tomo no. 314, 20 February 1992

${ }^{36}$ Popkin, Margaret, 2000, pp. 170-172

${ }^{37}$ History and politics of El Salvador, http://www.nationmaster.com/encyclopedia/ElSalvador, 2004-09-20

${ }^{38}$ Report of election observers, http://www.nonviolentways.org/elsal-032004.html, 2004$09-20$
} 


\section{Enforced disappearances of children}

\subsection{A strategy of the government forces}

During the civil war the government forces fought against the guerrilla movement, applying the doctrine of national security. Extrajudicial executions, disappearances and torture were widespread and in the majority of cases these crimes were committed by the armed forces of the government and its "death squads". One of the most repressive periods in the armed conflict took place between 1980 and 1984, when the government forces carried out "cleansing" operations of the civilian population. These military campaigns where designed according to the concept of counterinsurgency warfare, developed in the US, where the guerrilla only could be defeated by "taking the water away from the fish". This meant that the military operations were directed against the civil population. The largest operations were carried through in the conflict zones, which mainly were Chalatenango, Cabañas, Cuscatlán, San Vicente, Usulután, San Miguel, Morazán and the northern areas of San Salvador. ${ }^{39}$ (See map, Supplement A). The abduction of children was clearly one strategy in the larger pattern of violence directed against the civilian and peasant population, who was considered to support the guerrilla and its goals.

Various massacres, such as Río Sumpul, El Calabozo and El Mozote, took place in the beginning of the 1980's and it was usually in the context of massacres families became separated through the abduction of their children or parents were murdered and the surviving children taken by the soldiers. Some of the abducted children were taken to orphanages and other institutions, such as the Salvadoran Red Cross, and others were held at military bases or even kept in the houses of the soldiers and their families. Some of the children were eventually given up for adoption, either within the country or abroad. Salvadoran children who disappeared during the conflict have been found in the neighboring countries Honduras and Guatemala, and also in the US, France, Belgium, the Netherlands, Switzerland, Italy and the United Kingdom. ${ }^{40}$

There is no exact figure on the number of disappeared children. According to figures provided by the UN Working Group on Enforced Disappearances there are 2,661 reported disappearances, of which 391 cases have been clarified. The Working Group does not mention how many of these cases concern abducted children, but it acknowledges that children systematically

\footnotetext{
${ }^{39}$ La Paz en Construcción - Un Estudio sobre la Problemática de la Niñez Desaparecida por el Conflicto Armado en El Salvador, Asociación ProBúsqueda, 2003, p. 15

${ }^{40}$ Amnesty International Report, Where are the "disappeared" children?, 30 July 2003, AI INDEX: AMR 29/004/2003
} 
have been victims of enforced disappearance. ${ }^{41}$ The number provided by the UN Working Group is however far from the real number of disappearances - as many as 7,000 may have disappeared. An investigation by IDHUCA (Instituto de Derechos Humanos de la Universidad Centroamericana "José Simeón Cañas") reveals that various human rights groups in the country have registered 5,254 cases of enforced disappearances during the period between 1975 and $1994 .^{42}$ Since it started, the NGO specifically dealing with the issue of disappeared children, Asociación Pro-Búsqueda de Niñas y Niños Desaparecidos, has received 731 complaints of which 246 cases have been resolved. These figures are based on disappeared children of Salvadoran nationality under the age of 13 . However, this number does not represent the actual total of all cases of children who disappeared during the war, only those that have been denounced. ${ }^{43}$ (Read more about ProBúsqueda in chapter 3.4).

Not all disappeared children were abducted by the government forces, but by the FMLN. According to figures provided by Pro-Búsqueda these cases constitute about 7 per cent of the total amount of cases (51 of 731 cases). The majority of these children were separated from their families in order to serve as covers at so called "houses of security" in the capital and larger cities, from which the guerrilla operated. ${ }^{44}$ Other children that are denounced as disappeared were the victims of the circumstances of war and thus neither the victims of the government strategy nor the FMLN. The circumstances in these cases differ a lot from case to case.

The government denies that there existed a deliberate strategy to separate children from their families as an action to fight the guerrilla. Mr Mejía, who works for the Salvadoran government as the director of the Human Rights Department of the Ministry of Foreign Affairs, says that the disappearances of children never was a strategy of the government forces, but a consequence of the state of war that prevailed in the country at the time. ${ }^{45}$ This is not consistent with information from other sources. Some exsoldiers have declared that from 1982 they received orders to take with them children which they found during army attacks on the civil population. ${ }^{46}$ The PDDH has also declared that they are convinced that there existed a systematic practice to abduct children during armed forces operations. ${ }^{47}$

\footnotetext{
${ }^{41}$ Report of the Working Group on Enforced or Involuntary Disappearances, Civil and Political Rights, including the questions of Disappearances and Summary Executions, 21 January 2004, E/CN.4/2004/58

${ }^{42}$ La Paz en Construcción, 2003, p. 43

43 ibid., p. 24

${ }^{44}$ Article about the disappeared children in an internet newspaper, http://www. elfaro.net/Secciones/Especiales/Desaparecidos/Desaparecidos4_20030707.asp, 2004-10-12

${ }^{45}$ Interview with Mejía Trabanino, director of the Human Rights Division of the Ministry of Foreign Affairs, 11 November 2004

${ }^{46}$ Article about the disappeared children in an internet newspaper http://www.elfaro.net/ Secciones/Especiales /Desaparecidos/Desaparecidos3_20030707.asp, 2004-10-12 and La Paz en Construcción, 2003, p. 16

${ }^{47}$ Interview with Salazar Flores, PDDH, 24 November 2004; PDDH resolution about the Serrano Cruz case, 2 September 2004, pp. 3 and 8
} 


\subsection{Two illustrative cases}

The typical situation where children became separated from their families occurred during military operations in zones where the guerrilla had a stronghold. When the military launched an operation the civilian population tried to escape through hiding in the mountains, so called "guindas", which often went on for several days. This was the case for the Contreras family. 25 August 1982, the Fifth Infantry Brigade of the Salvadoran army carried out a military operation in the department of San Vicente. The civilian population was indiscriminately attacked and the inhabitants divided into groups and sought refuge in the mountains. However, the largest group was discovered and decimated by the soldiers. The survivors tried to escape the soldiers and, in the consequent confusion, the children became separated from their families. María Contreras lost three of her children in the incident: Julia, four months; Serapio, two years and Herminia, five years. She has testified that she saw a soldier take Herminia by the hair and carry her off and the same happened to Serapio and other children. María was carrying Julia but when she fell, the child slipped out of her arms. María had no choice but to carry on and leave her child to avoid falling in the hands of the soldiers and be killed. A soldier picked Julia up and carried her off. When the military operation came to an end, eighty civilians had been killed but María's children could not be found among the corpses. María began to search for her children and was told that they had been seen at the army headquarter at Río Frío. ${ }^{48}$ María could not seriously start to search for her lost children until the war ended.

The scenario of the disappearance was quite different when children were separated from their families by the FMLN. Pablo Mejía has testified that he was pressured and even threatened by a guerrilla leader to give up his two children, Fermín and María. The arguments used were the safety of the children and that they could serve a purpose as covers at a "house of security". Pablo never saw his children again after the man that was responsible for the two children was killed. ${ }^{49}$

\subsection{What happened to the children?}

The separation from their families and the following events has influenced the lives of the disappeared children in different ways - socially, legally and psychologically. Pro-Búsqueda is not only searching for a disappeared child but for a different person. It is essential to bear in mind that between thirteen and twenty-five years have passed since the children disappeared and that these children now are young adults.

\footnotetext{
${ }^{48}$ PDDH resolution, caso SS-0449-96, 30 March 1998, pp. 10-13

${ }^{49}$ La Paz en Construcción, 2003, p. 20
} 
The disappeared children can be divided into five different groups, depending on what happened to them after being separated from their families. Cases of children who were given up for adoption can be divided into two categories: those who were adopted through a formal, judicial process and those who were adopted "de facto". The latter means that the children were registered as the biological children of the adoptive parents they were appropriated. Other children grew up at orphanages or at military bases. The last group is those children who became subject of trafficking, which is characterized by the total eradication of the identity of the minor and therefore it is difficult to establish the actual situation for these children. Even though it has not been judicially proved that some of the disappeared Salvadoran children became victims of trafficking, Pro-Búsqueda has gathered evidence that the practice of selling children existed. ${ }^{50}$

According to various sources, there existed no less than 50 orphanages during the armed conflict. Most of the children came from the war zones. When the war ended the majority of those orphanages closed. The children who were forcibly separated from their families usually ended up at one of these orphanages. Many children were told that their families had abandoned them to join the guerrilla, which made them feel unwanted. At some of the orphanages it was common practice to give children up for adoption to other countries. When it was necessary to obtain a birth certificate, the orphanage caretaker could go to a municipal office and staff at the office then invented information about the identity of the child. Usually the children who were too old for international adoption standards were institutionalized at the orphanages. They also to a larger extent got to keep their own names, but their birth date, birth place and parents' names were altered. The changes of the identities have made the search for the children much harder.

Those children, who were adopted "de facto", ended up staying in a family environment. "De facto" adoption mainly concerned the younger children. For example, some members of the armed forces took children during military operations and brought them to their homes in order to raise them as their own. It was not only soldiers' families who adopted children this way. Many people knew that the armed forces brought children from the war zones to the military bases and some went there to claim a child, which they could bring up as their own. The war and the poor condition of civil registers created a climate in which the easiest solution to regulate the child's legal situation was to register the child as being biologically theirs. To this day many of these children do not know that they are adopted. ${ }^{51}$

Some of the abducted children were never taken to an orphanage, but ended up living at the military base they were first brought to. These children grew up in a military environment, which marked their lives with war and violence. This was, for obvious reasons, not a proper place for a child. The children were too young to be soldiers, so they helped with daily chores

${ }^{50}$ La Paz en Construcción, 2003, p. 27-28

${ }^{51}$ ibid., 2003, pp. 33-35 
around the military base. Being in the hands of the people who had captured them, and in many cases the people who had killed their family, these children grew up with feelings of shame and confusion. ${ }^{52}$

\subsection{The NGO "Pro-Búsqueda"}

Once the war had come to en end and the Truth Commission was set up in 1993, some families seriously began searching for their lost children, who in most cases had been missing for more than a decade. Many families affected by the disappearance of a child had been living in refugee camps in Honduras during several years and had now come back to El Salvador to live in repopulated communities. The first group of families who formed Pro-Búsqueda got united during the process of documentation of the human rights violations, which took place in Chalatenango, as a part of the work of the Truth Commission. Some parents began to file cases regarding their disappeared children through the legal system. The Jesuit Father Jon Cortina, who had initiated a local commission of human rights, supported these families and helped them prepare their demands at the Court of First Instance of Chalatenango. On the basis of these initial cases, other families joined in the efforts to reach truth and justice, and this led to the official formation of the Asociación Pro-Búsqueda de Niñas y Niños Desaparecidos in 1994, for which Father Cortina became the director and still is. ${ }^{53}$

Pro-Búsqueda has defined as its principal mission to "search for children who disappeared as a consequence of the armed conflict in El Salvador; and in the event they are found, respond to demands for truth, justice and reparation and to contribute to the creation of legal and institutional tools to find a solution to the problem". ${ }^{54}$ In order to complete this mission ProBúsqueda has several objectives. They obviously strive to promote the search of children missing because of the civil war and defend the rights of both the families and the found children (now young adults). Other objectives are to defend the children's right to an identity, promote the reconciliation and integration of families including adoptive families, and contribute to the moral and material compensation of the victims. ProBúsqueda seeks to promote the participation of governmental institutions and NGO:s and engage them in the problematic issue of disappeared children. Pro-Búsqueda also seeks to contribute to creating a historical record for the collective memory of the Salvadoran people. ${ }^{55}$

Pro-Búsqueda receives complaints and documents the cases. The NGO receives approximately 3-4 new complaints each month and by October 2004 Pro-Búsqueda had received and processed 731 cases of disappeared children. These cases are usually reported by family members, but also by

\footnotetext{
${ }^{52}$ La Paz en Construcción, 2003, p. 37

${ }^{53}$ El día más esperado, Pro-Búsqueda, 2001, UCA Editores: San Salvador, pp. 44-45

${ }^{54}$ Plan Estratégico de Pro-Búsqueda 1998-2000

${ }^{55}$ En Búsqueda, Identidad - Justicia - Memoria, publication of Pro-Búsqueda, época 2, vol. 9, August 2004, El Salvador, p. 5
} 
young adults who are searching for their roots and by independent sources. Pro-Búsqueda has an investigation team and their work is to start an investigation on the whereabouts of the child in question (or the biological family). The methods of investigation have been refined during ten years of experience. The sources of information are diverse, but the family or the "disappeared" person is the principal source from where the investigation takes off. The process of investigation has to adapt to the circumstances in each case. Through searches of orphanage and adoption records in El Salvador, as well as by the word of mouth, Pro-Búsqueda has succeeded in locating 246 children. ${ }^{56}$ When a child has been located a DNA-test is conducted so that there is no doubt that the family and the child are related to one another.

In those cases where the child has been located Pro-Búsqueda offers to sponsor a family reunion. Almost all the Salvadoran children (or at the time of being found, young adults) have been eager to learn about their roots and at least visit their families of origin. Of those found abroad, approximately 50 per cent have been able to come to El Salvador to visit their biological families. At the first family reunions the children are accompanied by a psychologist. In addition, Pro-Búsqueda offers group therapy for both the children and the families, since there are a lot of issues to deal with, especially for the found children, who often find themselves stuck between two worlds. ${ }^{57}$

Besides working at the individual level, Pro-Búsqueda is also working towards convincing the Salvadoran state that it should take on its responsibilities in terms of contributing to achieving truth and justice in such an important issue. For example, in 1999 Pro-Búsqueda presented the proposition of the creation of a National Search Committee before the legislative assembly (read more in chapter 4.6.1). Pro-Búsqueda has also, in cooperation with CEJIL (Centro por la Justicia y el Derecho Internacional), taken several legal initiatives, including presenting the Serrano Cruz case before the IACHR and the Inter-American Court. Besides this case, ProBúsqueda has also brought seven other cases to the Inter-American System of Human Rights. ${ }^{58}$

\footnotetext{
${ }^{56}$ Interview with the lawyer of Pro-Búsqueda, Victoria Ardón, 17 November 2004

${ }^{57}$ La Paz en Construcción, 2003, pp. 64-65

${ }^{58}$ Interview with the lawyer of Pro-Búsqueda, Victoria Ardón, 17 November 2004
} 


\section{Situation of the victims at the national level}

\subsection{The Truth Commission - from madness to hope}

The Salvadoran Truth Commission (STC) was set up after the war and received its mandate from the Peace Accords. ${ }^{59}$ It was one of few measures aimed at dealing with past abuses of human rights. The STC was given mandate to investigate "serious acts of violence that have occurred since 1980 and whose impact on society urgently demands that the public should know the truth”. The STC was also entrusted with making legal, political or administrative recommendations. The STC was brokered and verified by the UN and all three STC members were foreigners, for reasons of impartiality and credibility. The international composition of the STC and the recognition extended to it by the Salvadoran government and the FMLN ensured that its findings would have both authority and legitimacy. It worked during six months with the investigations, starting 13 July 1992, and had two additional months for elaborating the report. It was a difficult task the STC had to deal with, since it had thousands of cases of violations against human rights to document. Institutions and individuals were invited to denounce acts of violence to the STC, under guarantees of confidentiality. Offices were opened in various departmental capitals, such as Chalatenango, Santa Ana and San Miguel. The investigative staff of the STC was entirely non-Salvadoran. During the course of documentation and investigation, the STC received 22,000 denunciations and approximately 85 per cent of these could be attributed to the armed forces, paramilitary groups linked to the state or death squads. Only 5 per cent of the denunciations were connected to the FMLN. ${ }^{60}$

For many of the families of abducted children, the end of the war and the establishment of the STC meant that they finally could report the disappearances of family members to some kind of authority. In many cases more than ten years had passed since their children disappeared - it really went from madness to hope. Francisca Romero gave testimony before the STC delegation which had come to the village of Guarjila. She felt that this was a first step in the search of her disappeared daughter. The case of the disappeared Elsy Romero appeared in the report of the STC, but not the way Francisca had hoped for. Elsy's name was mentioned in a list attached to the report, which contained the names of approximately 18,000 victims. The systematic disappearance of children was not even mentioned anywhere in the report. This was a disappointment for the families who had high hopes

\footnotetext{
59 Article 5 of the Chapultepec Peace Agreement, entitled "End to Impunity"

${ }^{60}$ The Truth Commission Report: From Madness to Hope, 15 March 1993
} 
that the truth about the disappeared children would be revealed in the STC's report. $^{61}$

The report, named "From Madness to Hope: the 12-year war in El Salvador", contained detailed information about 32 illustrative cases in order to describe the general pattern of violence, including violence from both sides of the conflict. Lack of time and funds hindered a further investigation of the majority of the documented cases, which meant leaving a lot of questions without answer, including the destiny of those who disappeared. The report concluded that the basic human rights of thousands of Salvadoran men and women had been violated during the war years. To fulfil its official mandate, the STC proposed recommendations oriented towards the reconciliation and democratisation of the Salvadoran society. For example it recommended the formation of a judicial reform programme. When it came to the issue of punishing those responsible for violations the STC recognised that the current judiciary was not capable to apply the law to acts of violence committed during the armed conflict and also that doing so could impede the goal of national reconciliation. However, the report indicated that bringing the responsible to justice could be possible in the future, when the administration of justice had been restructured.

The STC aimed at promoting national reconciliation through recommendations designed to satisfy the victims' demands for justice and to encourage the Salvadoran society as a whole to acknowledge that crimes had been committed during the war. The STC stated that the truth is not enough to reach the goal of reconciliation - what is needed is an apology. The victims and, in most cases, their families are entitled to moral and material compensation. The construction of a national monument and the institution of a national holiday in memory of the victims should contribute to recognising the good name of the victims. Regarding material compensation the STC proposed that a special fund should be established. The fund should receive an appropriate contribution from the state but, in view of the prevailing economic conditions, should receive a substantial contribution from the international community. It also recommended that not less than 1 per cent of all international assistance that reached El Salvador be set aside for the purpose of compensating victims. ${ }^{62}$

The report of the STC was not only unique because it was sponsored and staffed entirely by the UN, but also because the members of the STC decided to publish the names of those who were found to be responsible for human rights violations. This was an extremely controversial decision, but the commissioners did establish a criterion to ensure that sufficient evidence was available before an individual was named. According to them, not to name names would be to reinforce the very impunity to which the parties instructed the STC to put an end. If there had been an effective system of justice in El Salvador at the time of the publication of the report, it could have used the report as a basis for an independent investigation of those

${ }^{61}$ El día más esperado, 2001, p. 43

62 The Truth Commission Report: From Madness to Hope, 15 March 1993 
guilty of violations. However, a reason for establishing the STC was that the parties to the peace accords knew that the Salvadoran justice system was corrupt, ineffective and incapable of rendering impartial judgments. If the parties had not wanted the STC to name names they could easily have said so. However, the mandate did not contain such a restriction. In addition, the initial contact between the STC and the parties clearly indicated that they assumed that the STC would identify individuals responsible for serious acts of violence. The attitude of the government changed as it became known that the STC had gathered incriminating evidence against high-ranking government officials, such as the minister of defence, General Ponce. The government started a diplomatic campaign against the publication of names, claiming that it would lead to a military coup. ${ }^{63}$

Once the report had been published, 15 March 1993, with the names of about 40 persons found guilty of violations of human rights, it was up to the Salvadoran government, and to some extent the FMLN, to comply with its recommendations. According to the Peace Accords the parties undertook to carry out the STC's recommendations. Regarding the recommendations aiming at democratisation, such as dismissals from the armed forces and from the civil service, the implementation level has been fairly high. The STC's recommendations have made a significant contribution to establishing a better balance between the executive, legislative and judicial organs, although reforms of the judicial system still needs to be consolidated. However, it should be noted that the implementation of some recommendations owed much to the lobbying efforts of the international community. In contrast, there was very little international pressure calling for the compensation of victims and their families or the other reconciliation measures and none of these elements of the recommendations have been implemented. $^{64}$

\subsection{Amnesty laws and impunity}

In October 1987 the first amnesty law was approved by the Salvadoran legislative assembly. This law conceded an absolute amnesty to the authors and persons involved in political crimes, common crimes with political ramifications or common crimes committed by no less than twenty people committed before the 22 October 1987. This law legally eliminated the possibilities of effective investigations, penal processes of responsible persons and adequate compensation for the victims and their families. ${ }^{65} \mathrm{In}$ January 1992, soon after the Peace Accords had been signed, the legislative assembly passed another amnesty law called the Law of National Reconciliation. This law applied to political crimes committed before

\footnotetext{
${ }^{63}$ Buergenthal, Thomas, 'The UN Truth Commission in El Salvador', Vanderbilt Journal of Transnational Law, 1994, vol. 27, issue 3, pp. 520-522

${ }^{64}$ Kaye, Mike, 'The Role of Truth Commissions in the Search for Justice', Reconciliation and Democratisation: the Salvadorean and Honduran Cases, Journal of Latin American Studies, 1997, vol. 29 issue 03, p. 712

${ }^{65}$ Ley de Amnistía, decreto no. 805, 27 October 1987
} 
January 1992. However, the amnesty did not apply to persons who, in accordance with the future STC's report, had participated in grave human rights violations since 1 January $1980 .^{66}$

Only five days after the publication of the report, the legislative assembly hastily passed the third amnesty law. This law, called the General Amnesty Law for the Consolidation of Peace ${ }^{67}$, was approved by a simple majority from the right-wing parties in the assembly. The FMLN was not a political party at the time and therefore it was not involved in the approval of the law, which however also benefited FMLN members. The law provided a broad, absolute and unconditional amnesty to all those involved in political crimes, common crimes with political ramifications or common crimes committed by no less than twenty people, committed before January 1992, whether or not they had been sentenced or judicial proceedings had been initiated against them or not. The law extinguished both civil and criminal responsibility and broadened the definition of what constitutes a political crime to also include crimes against public peace, crimes against judicial activity and crimes committed as a consequence of the armed conflict. This broader and unconditional amnesty law was justified by stating that the restrictions in the former law created a situation that lacked equity and that this was not compatible with the development of the democratic process. It was also stated that an unconditional amnesty was needed in order to promote and reach national reconciliation. ${ }^{68}$

The Salvadoran amnesty law is one of the broadest throughout Latin America and constitutes the most important cornerstone that upholds the prevailing impunity. Until now, there have only been investigations into a few prominent cases, such as the "Jesuit" case, but in general thorough and independent investigations have not been undertaken and therefore no one has been brought to justice for the human rights violations that took place during the civil war. As a result of the 1993 amnesty law, the members of the armed forces sentenced in 1991 for killing six Jesuit priests and two members of staff in 1989 were released. Despite decisions and recommendations made by international human rights bodies, the Salvadoran authorities continue to seek refuge under the unconditional amnesty law, which denies victims and their relatives access to justice.

The impunity in El Salvador arises from a lack of political will to deal with past abuses, which stems from the fact that the Salvadoran state itself or an arm of the state, the military, has committed or encouraged the vast majority of violations. Short before the presidential elections in March 2004, Antonio Saca, the ARENA party candidate, during an official visit at the PDDH declared that he considered the amnesty law necessary because the politics of "forgiving and forgetting" so far had maintained the social harmony in the country and had contributed to the national reconciliation. The human

\footnotetext{
${ }^{66}$ Ley de Reconciliación Nacional, decreto no. 147, 23 January 1992

${ }^{67}$ Ley de Amnistía General para la Consolidación de la Paz, decreto no. 486, 20 March 1993

${ }^{68}$ ibid., preamble articles III and IV
} 
rights Procurator, Beatrice de Carrillo, did not agree, but said that the amnesty law continues to be a problem which affects human rights and the victims of human rights violations. Furthermore, she said that it is in the hands of the Supreme Court to judge on the constitutionality of the amnesty law. ${ }^{69}$ The president's attitude is a good example of the non-existing political will when it comes to keeping the impunity. There does not seem to be any signs that the amnesty law of 1993 will be taken away in the near future. $^{70}$

The amnesty law of 1993 was unsuccessfully challenged by human rights groups before the constitutional division of the Supreme Court soon after its enactment. It is clear that the amnesty law of 1993 contravenes several provisions of the Salvadoran constitution. The Court, seemingly abdicating from its constitutional powers, ruled that it did not have jurisdiction over purely political questions, which it considered the amnesty law to be. Since the Court viewed amnesties as political acts, they were removed from the categories of laws which could be overridden by international law. The reasoning was similar in a case before the criminal chamber of the Supreme Court, where the Court found that the amnesty law was consistent with the Salvadoran constitution because the legislature had enacted the law through the sovereign power granted to it by the constitution. Since the amnesty law was not an ordinary law the Court found that it would prevail over treaty law and it also found that article 6(5) of the Protocol II of the Geneva Conventions justified the amnesty law. This provision states that the broadest possible amnesty should be granted to persons who have participated in the armed conflict. The Court emphasised that amnesty was necessary in order to reconstruct the country after the civil war and it also stressed that the amnesty was part of the negotiated Peace Accords. ${ }^{71}$

In 1997 and 1998 there were two new appeals to the Supreme Court, questioning the constitutionality of the amnesty law. In October 2000 the Court finally issued its decision where it ruled that the law was not unconstitutional per se, but that the amnesty law could not prevent actions in relation to violations of constitutional provisions, committed by state officials between 1 June 1989 and 1 January 1992. Judicial officials should make the decision whether or not to prosecute.

In 2003, the HRC considered the Salvadoran country report and a number of Committee experts questioned whether the amnesty law allowed victims of the armed conflict to obtain justice. In response, the Salvadoran delegation said that the amnesty law was part of the process of reconciliation provided

\footnotetext{
${ }^{69}$ Information om presidentvalet 2004, http://www.elecciones2004.com.sv/ NewsDetail.asp?ID=150, 2004-08-31

${ }^{70}$ Interview with Efrén Arnoldo Bernal Chévez, Member of Parliament representing FMLN, 11 November 2004

${ }^{71}$ Guevara Portillo Case, Sala de lo Penal de la Corte de Justicia, San Salvador, 16 August 1995
} 
for by the Peace Accords and it stated that the law respected all relevant international conventions to which El Salvador was a party. ${ }^{72}$

\subsection{Politics of negation}

To this day the Salvadoran government has not officially recognised that there existed a practice of enforced disappearance of minors during the armed conflict. Government representatives acknowledge that children became separated from their families as a consequence of the war, but they refuse to admit the responsibility of the state for this and even claim that families supporting the FMLN abandoned their children in order to get involved in the guerrilla activities and that the parents did not seem to care much about their children since it took such a long time before they started searching for them. ${ }^{73}$ FMLN, for its part, does not deny the fact that some children became separated from their families because of them. ${ }^{74}$

As a consequence of the Salvadoran state's unwillingness to recognise its responsibility in the issue of disappeared children, the victims' sufferings have not been taken seriously. None of the STC's recommendations regarding material and moral reparation to the victims have been implemented: no official pardon on behalf of the government has been given, no national monument has been set up, no national holiday of remembrance has been instituted and no fund for compensating victims has been established. The victims have also so far been denied what is most important to them - to find out the truth and serious investigations into the cases.

The most extreme form of negation of the problematic has been shown by some military personnel, who of course do not want to admit that children in conflictive zones systematically were abducted during the armed conflict. For example the retired General Mauricio Ernesto Vargas made the following statement in 1995:

"(This accusation about the disappeared children) is really like a novel by Gabriel García Márquez, or something like that... It never happened. Where are the children? Are they at some secret orphanage? Or did we eat the children? Fried? Roasted? Or boiled? I really do not understand why they continue with these stories. $^{, 75}$ (Translation by the author)

The politics of negation affects all levels of the Salvadoran society. The attitude at the General Prosecutor's office is illustrative for how the victims

\footnotetext{
${ }^{72}$ UN Press release: HRC considers civil and political situation in El Salvador, HRC $78^{\text {th }}$ Session, 23 July 2003

${ }^{73}$ Interview with Mejía Trabanino, Director of the Department of Human Rights, the Ministry of Foreign Affairs, 11 January 2004

${ }^{74}$ El día más esperado, 2001, p. 294

75 ibid., p. 25
} 
have been negated serious investigations. In 1993, five mothers accompanied by a lawyer from CDHES (Comisión de Derechos Humanos de El Salvador), went there to denounce the disappearances of their children. The prosecutor did not let them make the denunciations and instead started to insult the mothers and even called the police to make them leave. In addition, those cases which have been brought to local courts have not been properly investigated and consequently dismissed because of lack of evidence. These are the consequences of the politics of negation. ${ }^{76}$

\subsection{PDDH and the disappeared children}

In 1996 the PDDH received a complaint from Pro-Búsqueda which included a total of 145 cases of disappeared children. As a response to this complaint, the PDDH carried out an investigation. 30 March 1998, the human rights ombudsman signed a landmark resolution calling on the Salvadoran military and judicial authorities to undertake an investigation of the fate of children who disappeared during the war. This resolution relied on international law and on the Salvadoran constitution in order to establish that the amnesty could not bar the investigation and prosecution of these cases. ${ }^{77}$

In more detail, the PDDH issued a decision in five of the 145 cases, in which the enforced disappearance of eight children was established: Elizabeth Carrillo Panameño (5 years at the time of her disappearance); Leonor López Rodríguez (2); Herminia (5), Serapio (2) and Julia (4 months) Contreras; Erlinda (7) and Ernestina (3) Serrano Cruz; and José Rivera (3). The PDDH concluded that members of the Salvadoran armed forces were responsible and that the disappearances had taken place during various military operations in which non-combatant civilian population was attacked by military forces. The PDDH pointed out which military units were responsible for the abductions and also named two local court judges, accusing them of not having handled the cases concerning disappeared children properly. Among its recommendations, the PDDH urged the National Defence Minister and the Joint Chief of Staff to order investigations and present the results to the competent judges in order to deduce the relevant criminal responsibilities and to establish the whereabouts of the children and return them to their families, if such a measure would be in the best interest of the child. In its decision the PDDH also ordered material and moral reparation for damages caused to the victims. The officials mentioned above were urged to co-operate with the legal system in bringing those responsible to justice. The PDDH also encouraged the Salvadoran government to sign and ratify the InterAmerican Convention on Forced Disappearance of Persons. ${ }^{78}$ The report and its recommendations were ignored by the Salvadoran state.

\footnotetext{
${ }^{76}$ El día más esperado, 2001, pp. 45-46

${ }^{77}$ Popkin, Margaret, 2000, p. 174

${ }^{78}$ PDDH Resolución, 30 March 1998, caso SS-0449-96
} 
From the end of 2001 Pro-Búsqueda has collaborated on a permanent basis with the PDDH, for example informing the PDDH about its efforts to influence the state to initiate investigations regarding the disappeared children. In March 2002 Pro-Búsqueda submitted information about four new cases, involving five disappeared children, to the PDDH and in February 2003, the PDDH issued another resolution regarding the disappeared children. This resolution mainly considers the state's obligations to deal with past violations of human rights. Among its recommendations the PDDH urges the Salvadoran state and the concerned authorities to investigate and inform the affected families, as well as the society, about the truth and facts of the disappearances, to sanction those found responsible and to afford the victims with adequate reparation. ${ }^{79}$

In February 2004 Pro-Búsqueda presented a communication to the PDDH, reporting its concern about the Serrano Cruz case before the Court of First Instance in Chalatenango. There were indications that due process had not taken place, especially regarding the investigative actions of the prosecutor. For this reason, Pro-Búsqueda requested the PDDH to verify that the rules of due process were being observed in the case and that the Procurator, Beatrice de Carrillo, should comment on the results of this verification. In September 2004 the PDDH published a comprehensive report regarding the Serrano Cruz case. The PDDH carried through a detailed investigation of the disappearance and how the Salvadoran state and its authorities had handled the case. ${ }^{80}$ The results of the PDDH investigation is of interest not only to the victims but also to the Salvadoran society in general and those who govern the country. It is a call of preoccupation for the system of justice and an exploration of the conscience of those sectors that uphold the structure of impunity, which is institutionalised in El Salvador. ${ }^{81}$

\subsection{Habeas corpus}

The constitutional division of the Supreme Court has at various occasions issued decisions in relation to writs of habeas corpus ${ }^{82}$ filed by the families of disappeared children. According to article 11 of the Salvadoran constitution all persons have the right to a habeas corpus when any individual or authority illegally or arbitrarily has restricted his/her freedom. Between 1995 and 1998 three families, participating in Pro-Búsqueda, have filed writs of habeas corpus. First to do so was the mother of the Serrano Cruz sisters. In March 1996 the Supreme Court wrote in its decision that

\footnotetext{
${ }^{79}$ PDDH Resolución, 10 February 2003, expediente SS-0449-96, pp. 3, 22-23

${ }^{80}$ Interview with Luis Salazar Flores, Procurator for Children and Youth, 24 November 2004

${ }^{81}$ PDDH Resolución, 10 February 2003, expediente SS-0449-96, p. 3

${ }^{82}$ Habeas corpus (or remedy of amparo) means that any person may present an appeal to a competent court for a writ of amparo on behalf of a person subject to illegal detention. The court may order the detainee to be brought before it and may order his/her immediate release after investigation of the legal situation, rectify the irregularities of his arrest or place him at the disposal of a competent judge.
} 
habeas corpus is a mean to obtain liberty for a person who has been detained against the law and not a mean to investigate the whereabouts of a person illegally detained thirteen years ago. Since the Batallón Atlacatl, which was responsible for the disappearance, did not exist anymore, the military in chief could not be held responsible. In addition to this, there were no known cases of persons who were continuously held detained at military installations. Due to this reasoning, the Supreme Court found that habeas corpus was not the adequate way to deal with the problems of disappearances, which occurred during the conflict. The outcome was the same in the following two Supreme Court resolutions regarding disappeared children. $^{83}$

In October 2002, the mother of the Contreras children (see chapter 3.2) filed a writ of habeas corpus before the constitutional division of the Supreme Court. In February 2003, the Court issued its decision where it recognised the "constitutional violation of the right to physical freedom" of the three children, and urged the Attorney General's Office "to take the necessary measures, in line with its constitutional powers, to establish the condition and whereabouts of the disappeared children, with the aim of safeguarding their fundamental right to freedom”. To date the Attorney General's Office has not taken any measures in this regard. ${ }^{84}$

\subsection{Creation of a national search commission?}

\subsubsection{The efforts of Pro-Búsqueda}

Pro-Búsqueda has endeavoured to convince the Salvadoran government that it should take on its responsibilities in terms of resolving the important issue of disappeared children. In 1999, Pro-Búsqueda published a report about its investigations and one of the principal recommendations in this report was that a search commission should be established. This led to the presentation of a proposal for the creation of a "Comisión Nacional de Búsqueda de Niñas y Niños Desaparecidos de El Salvador" (CNB) to the legislative assembly in October 1999. This proposal set out "the need for an operating structure to be established, chaired by a council made up of the state institutions and civil society organisations competent in the issue, a technical committee with focus on law, social and psychological work and the appointment of an executive director responsible for implementing and fulfilling the council's agreements. In addition it should have a clear budget with which to operate". The proposal was supported by members of the Family, Women and Children's Committee of the legislative assembly and was referred for further study and processing within that Committee.

\footnotetext{
${ }^{83}$ Agotamiento de los recursos internos como requesito para accesar al sistema interamericano de protección de los derechos humanos, Pro-Búsqueda, pp. 2-3

${ }^{84}$ Amnesty International Report, Where are the "disappeared" children?, 30 July 2003
} 
The proposal of the creation of a CNB gave hope to hundreds of families which still had not been able to find their disappeared children. ProBúsqueda had high hopes that a future cooperation with governmental institutions and the possibility to obtain information from the armed forces would make the process of investigation considerably easier. ${ }^{85}$ In addition to this, a CNB would have a great historical impact, since it would have been the first time that the Salvadoran state recognised the problem of disappeared persons. ${ }^{86}$

The main opposition to the project of establishing a CNB came from the armed forces. This was not a surprise, since it mainly was the armed forces which were responsible for the disappearances of children. When the formation of a CNB was discussed in the legislative assembly, 22 November 2000, the positions of the political parties were heard. Father Cortina opened the meeting and after him Elsy Romero, one of the disappeared children who first were found, told her story. Thereafter, the positions of the political parties followed. The ARENA representative rejected the creation of a CNB with reference to that this type of work fell within the faculty of the Procurator General. The PDC representative, to the contrary, supported the CNB proposal. The FMLN representative recognised that his party had a historical responsibility regarding the disappeared children and manifested that FMLN was willing to cooperate with Pro-Búsqueda in its efforts to find the children. Lastly, the PCN also manifested its willingness to support the CNB. Even though the discussion mainly showed that the parties in the legislative assembly were in favour of the CNB, the result of the plenary was another. Father Cortina confirmed that he had felt that the right-wing parties already had agreed to not permit the creation of a CNB and that the speeches did not have much significance. This showed, not surprisingly, that there existed more powerful interests that influenced the political parties, which were more persuasive than the plead of the affected families to establish a CNB. ${ }^{87}$

In November 2000 the Family, Women and Children's Committee concluded that it had not reached the necessary consensus to issue a favourable opinion. It noted the existence of a "similar Committee established by the executive and coordinated by the Procurator General's Office, which is working on this very issue". This Committee, also known as the Procurator General's Working Group, had neither a budget or organic structure, nor any institutional support for its operations, both of which elements were included in the proposal for a CNB. In March 2002, after more than a year of efforts, Pro-Búsqueda decided to withdraw from the Procurator General's Working Group as it was not making any progress whatsoever in terms of moving forward with the agreed work plan or on the 13 cases prepared by the organisation. In April 2002 Pro-Búsqueda reiterated its petition of the creation of a CNB before the legislative assembly, but without success. Pro-Búsqueda has continued its efforts to

\footnotetext{
${ }^{85}$ Interview with Victoria Ardón, Pro-Búsqueda, 17 November 2004

${ }^{86}$ La Paz en Construcción, 2003, p. 67

${ }^{87}$ El día más esperado, 2001, pp. 292-294
} 
make the creation of a functioning CNB a reality, which would provide legal backing to the activities of the NGO. ${ }^{88}$

\subsubsection{The PDDH}

In March 2002 the PDDH publicly expressed its position in the question of a CNB, which was remitted to the legislative assembly. The PDDH made clear that the adoption of judicial, legislative and administrative means in order to re-establish the identity of the disappeared children is a legal and moral imperative of the Salvadoran state, which is of great importance and urgency. The PDDH stated that the state mechanisms had not functioned and that it was only thanks to the work of Pro-Búsqueda that some cases had been solved. The PDDH recognised the fact that the identity of those affected was not even close to be re-established and concluded that there had not existed any political will to make the state mechanisms work. The creation of a CNB would be a viable alternative for the Salvadoran state with the purpose to fulfil its obligations towards the victims of enforced disappearances of children. The PDDH also pointed out that the resolved cases have showed that finding the disappeared children do not cause social instability and therefore creating a CNB to provide the victims with the truth is the least the Salvadoran state could do. ${ }^{89}$ This position of the PDDH is confirmed by Salazar Flores, the procurator for children and youth. ${ }^{90}$

\subsubsection{An Inter-institutional Commission}

5 October 2004, the creation of an Inter-institutional Commission for the Search of the Disappeared Children was ordered by the executive organ through a decree. This decree acknowledges that children were separated from their families during the armed conflict, but it neither attributes any of the responsibility to the armed forces nor mentions that children were systematically abducted. The objective of this commission is that various public institutions, such as the National Defence Ministry, the PNC, the Office of the Public Prosecutor and the Procurator General of the Republic, should cooperate in the search for the children who are still missing. The Commission will be in function during a period of four years. ${ }^{91}$

However, this Commission will probably not contribute much to finding the truth, since the institutions involved in it has not showed any interest before in solving the issue. Those who know most about the disappeared children, i.e. the civil society in general and Pro-Búsqueda in particular, have not been included in the Inter-institutional Commission. To publicly express their rejection of the recently formed Commission, several human rights

\footnotetext{
${ }^{88}$ PDDH Resolución, 10 February 2003, expediente SS-0449-96, pp. 5-6; Interview with Victoria Ardón, Pro-Búsqueda, 17 November 2004

${ }^{89}$ PDDH Resolución, 10 February 2003, expediente SS-0449-96, pp. 4-5

${ }^{90}$ Interview with Salazar Flores, Procurator for Children and Youth, 24 November 2004

${ }^{91}$ Decreto no. 45, Diario Oficial, Tomo No. 365, No. 185, 6 October 2004, p. 12
} 
organisations, with Pro-Búsqueda in front, carried through a demonstration 4 November 2004. The families who have lost their children demanded that Pro-Búsqueda should be integrated in the Commission, in order to give it some credibility. The demonstration march was intended to head for the Presidential House, but was hindered by police forces. ${ }^{92}$ The Commission will most likely not be able to guarantee the transparency or impartiality. The creation of an Inter-institutional Commission was probably only a consequence of the Serrano Cruz case, which has been considered by the Inter-American Court, and an argument that the Salvadoran state could use as a defence before that Court. Because of this the victims will not come any closer to the truth than before the creation of this Commission. ${ }^{93}$

\subsection{National monument}

The construction of a national monument in memory of the victims of the armed conflict was one of the recommendations to the Salvadoran government, contained in the STC's report, as part of the moral compensation to victims. Because of the politics of negation and the prevailing impunity this recommendation was not taken seriously by the government. Instead, national NGO:s formed a Committee in Favour of the Monument to the Civilian Victims of Human Rights Violations (Comité Pro Monumento de las Víctimas Civiles de Violaciones de Derechos Humanos). Pro-Búsqueda was a part of this Committee, which worked towards dignifying the victims of armed conflict. The initiative to recognise the good name of the victims through a national monument never had the support of the Salvadoran authorities, but finally, thanks to the persistent efforts of the Committee, the Monument to Memory and Truth has become a reality. The state has not yet acknowledged the monument.

The monument, which was inaugurated in 2003 in Parque Cuscatlán in San Salvador, pays sincere homage to those civilians who were killed or who disappeared during the armed conflict in El Salvador. An 85-metre wall of black granite immortalises the names of more than 25,000 girls, boys, women and men, who were innocent victims of the conflict. "A space for hope, where we can continue dreaming and build a more just, human and equitable society” reads the inscription on the monument. Pro-Búsqueda has also, on its own initiative, contributed to the process of moral reparation of the victims of enforced disappearances of children, through erecting small monuments of memorial on three places where children were abducted; in the departments of Chalatenango, Usulután and San Vicente. ${ }^{94}$

\footnotetext{
${ }^{92}$ Article in the newspaper La Prensa Gráfica, http://archive.laprensa.com.sv/20041104/ nacion/36715b.asp, 2005-02-02

${ }^{93}$ Interviews with Victoria Ardón, 17 November 2004; Salazar Flores, 24 November 2004; Miguel Rogel Montenegro, 9 December 2004; Guadalupe Mejía Delgado, 2 December 2004; Pedro Cruz, 15 January 2005; Engracia Chavarría, 15 December 2004; Bernal Chévez, 11 November 2004

${ }^{94}$ En Búsqueda: Identidad -Justicia - Memoria, publication of Pro-Búsqueda, época 2, vol. 6, September 2003, San Salvador
} 


\subsection{What remedy do the victims want?}

The first international meeting of found children, now young adults, who disappeared during the armed conflict took place between 18 and 21 July 2002 in San Salvador. This event was an attempt to generate a space for reflection of the problematic issue of disappeared children, in order to contribute to the reconstruction of the personal and social identity of those who had been found and the families who suffered from an enforced disappearance of a child. During this meeting the young men and women who have been found discussed what they want to be done on behalf of the Salvadoran state, the armed forces and the FMLN. They focused on the construction of a historical memory and on the question of national reconciliation, but they also stated that truth is an individual right and a way to repair the pain and suffering the armed conflict has caused the disappeared children and their families. Towards the end of the international meeting the participants agreed on six demands:

1. That a National Search Committee should be created in order to investigate the fate of the disappeared children and to promote reunions between them and their biological families. This would be the best way for the Salvadoran state to fulfil its obligations.

2. That the children and their families should receive a public apology and that the abduction of children during the conflict is declared as a violation of human rights. This would be a first step towards a real national reconciliation.

3. That laws are created which guarantee the respect and of the right to an identity of all found children and those who remain disappeared.

4. That the 10 of January is declared as National Remembrance Day for the disappeared children.

5. That an economic fund is created in order to support the young found persons, through scholarships, psychological attention and opportunities of personal development.

6. That a monument is created so that the memory of the disappeared children is kept alive. ${ }^{95}$

In short, what the victims of the enforced disappearances of minors most of all want is the truth and that those involved, the Salvadoran state, the armed forces and the FMLN, contribute and collaborate in the efforts to find it. In addition, it is important that the victims' suffering is being recognised by the state (moral reparation) and that they should be afforded some form of material reparation. At this moment, justice in terms of bringing those responsible before court is not an important question. First the government has to recognise the rights of the victims and then the question of justice might be discussed. ${ }^{96}$

\footnotetext{
${ }^{95}$ En Búsqueda: Identidad - Justicia - Memoria, publication of Pro-Búsqueda, época 2, vol. 3, October 2002, San Salvador, p. 11

${ }^{96}$ Interviews with Victoria Ardón, 17 November 2004; Mejía Delgado, 2 December 2004;

Rogel Montenegro, 9 December 2004
} 


\section{The Serrano Cruz case and the Inter-American System}

Like the Council of Europe, the Organization of American States (OAS) ${ }^{97}$ has a system for the protection of human rights. A central body of the OAS is the IACHR, which is based on the civil, political, economic, social and cultural rights in the American Declaration of the Rights and Duties of Man. ${ }^{98}$ More importantly, the IACHR acts as a body of the ACHR. ${ }^{99}$ The IACHR has seven independent members and deals with individual complaints procedures against state parties of the ACHR. Apart from individuals, NGO:s are also entitled to file complaints. When a petition is received, the IACHR decides on the admissibility. If a friendly settlement cannot be reached it adopts a report, which contains recommendations and this report is transmitted to the state in question and it is usually published. Within three months the state or the IACHR may submit the case to the Inter-American Court of Human Rights, if the state in question has accepted the Court's jurisdiction.

The Inter-American Court of Human Rights was established in 1979 in San José, Costa Rica. It has the optional competence to decide, through a binding and final judgment, on the individual complaints which have been referred to it by governments or by the IACHR. However, the Court has to this date only rendered 34 judgments on the merits. In accordance with article 63 ACHR, the Court can issue provisional measures and may rule that comprehensive reparations be made. ${ }^{100}$

\subsection{The Serrano Cruz case - background}

In the end of May and the beginning of June 1982, the Salvadoran armed forces launched an operation in the department of Chalatenango. It was called "Operación Limpieza" (cleansing operation). Several military units participated in the operation: Batallón "Atlacatl” and "Belloso"; the Fourth Infantry Brigade; the Air Force; and the Artillery Brigade.

2 June 1982 the sisters Erlinda and Ernestina Serrano Cruz (3 and 7 years old) had been hiding in the surrounding mountains of the municipal of San Antonio La Cruz for several days with their family. The older sister, Suyapa, witnessed the abduction of Ernestina and Erlinda. When they were hiding from the soldiers Suyapa's baby started to cry. Because of that she found it better to leave the girls so that they all would not be killed. After

\footnotetext{
97 There are 35 member states in the OAS.

${ }^{98}$ Issued 2 of May 1948

${ }^{99}$ ACHR entered into force in 1978 and is currently binding 24 state parties.

${ }^{100}$ Nowak, Manfred, Introduction to the Human Rights Regime, 2003, Martinus Nijhoff: Leiden, Boston, pp. 191-194
} 
that, Suyapa, who hid nearby, heard that the soldiers had found Ernestina and Erlinda and that they were discussing what to do with the girls. Finally, the soldiers took the two children with them. Suyapa could not do anything from fear of being killed, but had to silently witness the abduction of her sisters. It has been confirmed by a witness that the sisters were taken by helicopter to the city of Chalatenango, where they were taken care of by staff from the Salvadoran Red Cross. After that, the fate of the sisters is unknown. The father of the children was killed in an army operation in 1985 and after that the rest of the family went to a refugee camp in Honduras. ${ }^{101}$

\subsection{The legal process in El Salvador}

The Serrano Cruz family did not denounce the disappearances before competent authorities until 1993. This was because of the fear that the population had during the war years to denounce violations of their rights. 30 April 1993, the mother, María, finally denounced the abduction of Ernestina and Erlinda before the Court of First Instance of Chalatenango (Juzgado de Primera Instancia de Chalatenango, caso 112-93), claiming that Batallón Atlacatl was responsible for the disappearance of her daughters. The witness to the fact that the sisters had been brought to Chalatenango by helicopter could not be located in the judicial investigation and the petitioner could not remember the exact place where the abduction occurred. Because of this the judge decided to archive the case, without having conducted any serious investigations.

In 1995 María filed a writ of habeas corpus before the constitutional division of the Supreme Court (see chapter 4.5). It decided that habeas corpus was not the adequate way to deal with the problems of disappearances, which occurred during the conflict and that it was the Court of First Instance of Chalatenango which had to continue the process. Therefore the case was remitted to this court for further investigations. The case was reopened at the Court of First Instance of Chalatenango in April 1996. This time, the judicial action was limited to sending a letter to the Chief Major of the State (Jefe del Estado Mayor) requiring information. He denied that Batallón Atlacatl had been present in Chalatenango at the time of the disappearance of the Serrano Cruz sisters. The Court also requested information from the Salvadoran Red Cross, which said that the Serrano Cruz sisters could not be found in their registers. The Court did not conduct any further investigations and in March 1998 the case was archived for the second time. ${ }^{102}$ The PDDH has stated that the judge and the prosecutor acted illegal when they decided to archive the case, because of the omission of serious investigation. ${ }^{103}$

\footnotetext{
${ }^{101}$ PDDH Informe sobre el caso Serrano Cruz, 2 September 2004, pp. 39-42

102 Agotamiento de los Recursos Internos como Requisito para Accesar al Sistema Interamericano de Protección de los Derechos Humanos, pp. 1-3

${ }^{103}$ PDDH Informe sobre el caso Serrano Cruz, 2 September 2004, p. 57
} 


\subsection{The IACHR}

Because of the lack of investigation into the case by the Salvadoran legal authorities, Pro-Búsqueda, in co-operation with CEJIL, filed a complaint to the IACHR in February 1999, alleging that El Salvador was internationally responsible for the enforced disappearance of the sisters and for the subsequent failure to investigate the matter and provide reparation. CEJIL is an NGO, which primarily is dedicated to using the tools offered by the Inter-American System of Human Rights in order to defend human rights in the American hemisphere. CEJIL assists local NGO:s which decide to bring cases to the IACHR, with legal assistance. CEJIL is currently representing 20 per cent of the cases at the IACHR and 80 per cent of the cases before the Court. ${ }^{104}$

In their complaint, Pro-Búsqueda and CEJIL alleged that several rights of the ACHR had been violated: the right to life (art. 4), the right to personal integrity (art. 5), the right to personal liberty (art. 7), the right to a fair trial (art. 8), the right to protection of the family (art. 17), the right to a name (art. 18), the rights of the child (art. 19) and the right to judicial protection (art. 25 ), all in violation of the general duty to respect and guarantee the rights recognised in the ACHR (art. 1(1)). The Salvadoran state maintained that judicial proceedings still were open in the Court of First Instance of Chalatenango and therefore requested the IACHR to find the case inadmissible for failure to exhaust domestic remedies.

In February 2001, after examining the domestic legal proceedings, the IACHR found the case admissible. It concluded that "as of the date this report was adopted, domestic remedies had not operated with the effectiveness required to investigate a complaint of forced disappearance - a category of serious human rights violations. In fact, nearly eight years have passed since the first complaint was lodged with the authorities in El Salvador, with no definitive finding of how the events transpired". ${ }^{105}$ After issuing their decision on admissibility, the IACHR tried to find a friendly settlement, which was accepted by both Pro-Búsqueda/CEJIL and the Salvadoran government. However the petitioners decided to withdraw from this in January 2002 since there did not seem to exist any real political will on part of the state to comply with the presented proposal of a friendly settlement. ${ }^{106}$

In March 2003 the IACHR issued a report on the Serrano Cruz case. It recommended the Salvadoran state to investigate the case in a complete, impartial and effective manner, in order to establish the whereabouts of the sisters and in the case they are found, the state should provide reparation.

\footnotetext{
${ }^{104}$ Interview with Gisela de León, lawyer at CEJIL, 1 February 2005

${ }^{105}$ Serrano Cruz v. El Salvador, Report no. 31/01, 23 February 2001, paragraph 23

${ }^{106}$ El caso de las hermanas Serrano Cruz: Una luz de esperanza para cientos de niños y niñas desaparecidas en el conflict armado de El Salvador, CEJIL, Primer Congreso Internacional sobre Derechos Humanos ”Herbert Anaya Sanabria”, San Salvador 25-26 October 2004, p. 6
} 
The IACHR also recommended that the responsibility of the violation of human rights should be determined. ${ }^{107}$

\subsection{The Salvadoran legal actions after 1999}

When the Salvadoran state was notified that the Serrano Cruz case had been brought to the IACHR, the case was reopened a second time in June 1999. This time the prosecutor in charge asked the delegation of the International Committee of the Red Cross in El Salvador if it had cared for the Serrano Cruz sisters in 1982. The delegation answered that they had no record which confirmed that and it had not received any requests from the family of the Serrano Cruz sisters. The prosecutor also, at on-site inspections, tried to get information from the military, but had no success since he needed to have the permission from the Ministry of National Defence. In another case of inspection the archive was claimed to have been destroyed in an FMLN attack. $^{108}$

As a response to the fact that the Serrano Cruz case was brought to the InterAmerican Court the Salvadoran judicial authorities, with beginning in October 2003, aimed its investigations at trying to prove that the sisters had never existed. This is the reason why the PDDH, on request from ProBúsqueda, did some investigations of its own in 2004 and wrote a comprehensive report on the Serrano Cruz case. The prosecutor had six persons, some of them distantly related to the children's mother or father, who gave testimony that they had never heard of the existence of Erlinda and Ernestina Serrano Cruz. The prosecutor also tried to prove the inexistence of the sisters by claiming that the registers of baptism were not authentic.

The prosecutor visited a woman, who in 1997 had witnessed that she had seen the Serrano Cruz sisters get out of a helicopter and into a Red Cross vehicle. Through intimidating methods the judicial authorities made this witness claim, that she gave the earlier testimony only as a favour to the mother of the children, and that she had never seen the Serrano Cruz sisters. When the PDDH talked to the witness, she said that one day in October 2003, four armed men had come to her house, one of them was the judge and the others were from the prosecutor's office. They more or less put the words in the witness' mouth and she was too afraid not to do as the men told her. The next day the witness was taken to the Court of First Instance of Chalatenango where she signed a document, whose content she was unaware of since she was illiterate. The PDDH read the document to the witness and she then said that its content was not true and that her first

\footnotetext{
${ }^{107}$ En Búsqueda, Identidad - Justicia - Memoria, publication of Pro-Búsqueda, época 2, vol. 6, September 2003, p. 5

${ }^{108}$ Agotamiento de los Recursos Internos como Requisito para Accesar al Sistema Interamericano de Protección de los Derechos Humanos, p. 4
} 
testimony (in 1997) was the correct one. In July 2004 the prosecutor at several occasions tried to pressure the witness to go to San José for the audience in September to give testimony before the Inter-American Court. ${ }^{109}$ In the end, the witness went to San José to give false testimony of the non-existence of the Serrano Cruz sisters, but the PDDH made sure that the Inter-American Court had a copy of its report regarding the Serrano Cruz case where the actions of the Salvadoran judicial authorities is described in detail. ${ }^{110}$

\subsection{The Inter-American Court}

The Salvadoran state did not comply with any of the recommendations of the IACHR, with reference to the fact that they were only recommendations and therefore not binding upon the state. Because of this, the IACHR referred the case to the Inter-American Court the 14 of June $2003 .{ }^{111}$ It was the first time a Salvadoran case would be considered by this court.

1 September 2003, the petitioners presented their application with arguments and evidence, through written correspondence with the Court. In this writing Pro-Búsqueda and CEJIL indicated which rights in the ACHR had been violated (the same articles as were claimed before the IACHR) and they also requested that the Court should order the state to adopt certain measures of reparation. 31 October 2003, the Salvadoran state presented its preliminary objections and it also responded to the demands and arguments which the petitioners had put forward.

7 and 8 September 2004, an audience was held at the Court in San José. The audience was divided into two parts. The first part dealt with preliminary objections. The Salvadoran state presented three objections. First the state alleged that the Court did not have competence to decide on the case since the violations of the girls' rights occurred before 6 June 1995, the date when El Salvador accepted the jurisdiction of the Court, a so called question of rationae temporis. The second objection was that the Court could not deal with the case because the violations occurred during the armed conflict and therefore international humanitarian law should be applied instead of human rights law. Lastly, the state insisted that the Court should abstain from deciding upon the case since the penal process in El Salvador to determine the responsibility for the disappearance of the sisters was still open.

CEJIL and Pro-Búsqueda, for their part, alleged that the Court had competence to deal with the case, because a forced disappearance is a continuing violation which continues being committed until the fate of the victim is known and this means that the Salvadoran state has violated

\footnotetext{
${ }^{109}$ PDDH Informe sobre el caso Serrano Cruz, 2 September 2004, pp. 29-32

${ }^{110}$ Serrano Cruz v. El Salvador, Corte Inter-Americana, Excepciónes preliminares, Sentencia de 23 de Noviembre de 2004, paragraphs 38 and 40

${ }^{111}$ El Salvador recognised the jurisdiction of the Inter-American Court 6 June 1995
} 
human rights after the date it accepted the competence of the Court. The petitioners also claimed that the Court had competence rationae materiae, since human rights standards always are applicable, even in times of war. Finally, they stated that if the national recourses had not been exhausted, it had at least been an unjustifiable delay in the procedure of the case. ${ }^{112}$

The second part of the audience dealt with the questions of responsibility and reparation. Witnesses from both parties were presented. The testimonies presented by the petitioners aimed at proving the disappearance of the sisters, the pattern of disappearances of children as a consequence of the armed conflict and to answer to the Salvadoran state's allegation that the two sisters never had existed. ${ }^{113}$ Pro-Búsqueda and CEJIL requested that the Court should declare that the Salvadoran state was responsible for the enforced disappearance of the Serrano Cruz sisters. Regarding reparation the petitioners requested that the state should carry through a serious and exhaustive investigation with the goal to establish the whereabouts of the sisters, adequately repair the victims and identify, judge and sanction the persons found responsible for the abduction of the Serrano Cruz sisters. In addition, the petitioners demanded that a CNB and a reparation fund for found disappeared children should be created and that a public apology should be given to those affected by the disappearance of children during the armed conflict.

23 November 2004, the Court issued its judgment concerning the preliminary objections, put forward by the state. The second and the third exceptions were rejected but objection number one, regarding rationae temporis, was partly accepted. The Court thus decided that it was only competent to judge on facts that had taken place after the date El Salvador recognised the jurisdiction of the Court. ${ }^{114}$ In March 2005, the InterAmerican Court published its judgment on the merits regarding the Serrano Cruz sisters. The Inter-American Court examined the national legal processes in the Court of First Instance of Chalatenango and the constitutional division of the Supreme Court in order to determine whether El Salvador had breached articles 8 and 25 of the ACHR. The Court found that El Salvador had violated these articles to the detriment of both the sisters and their family. As a consequence of this breach, the Court also found that the family's right to personal integrity (article 5 of the ACHR) had been violated. ${ }^{115}$ Regarding reparation the Court ordered that the Salvadoran state should pay compensation mainly for immaterial damages caused to the victims and it also judged that other forms of reparation would be appropriate. This should include proper investigations, identifying and

\footnotetext{
${ }^{112}$ El caso de las hermanas Serrano Cruz: Una luz de esperanza para cientos de niños y niñas desaparecidas en el conflict armado de El Salvador, CEJIL, Primer Congreso Internacional sobre Derechos Humanos ”Herbert Anaya Sanabria”, San Salvador 25-26 October 2004, p. 6

${ }^{113}$ Comunicado de Prensa de Pro-Búsqueda: Audiencia ante la Corte Inter-Americana, 7-8 Septiembre 2004, p. 2

${ }^{114}$ Serrano Cruz v. El Salvador, Excepciónes preliminares, Sentencia de 23 de Noviembre de 2004, p. 29

${ }^{115}$ Serrano Cruz v. El Salvador, 1 March 2005, paragraphs 107 and 115
} 
sanctioning responsible persons and conducting a serious search of the victims. The Court also called for a functioning search commission, the creation of a search web page, the creation of a genetic information system, a public act where the state recognises its responsibility and medical and psychological assistance. ${ }^{116}$

\subsection{Consequences of the Serrano Cruz case}

In a country where impunity affects every level of the state apparatus, the prospects for victims to obtain truth, justice and reparation are small. The mechanisms for redressing human rights violations do not work on the national level and therefore the matter has to be brought to the international level, in this case the Inter-American System of Human Rights. The Serrano Cruz case, as the first Salvadoran case accepted by the Inter-American Court, has the possibility to open the door to overcoming impunity. However, the fight against impunity does not succeed over night, but is a long process. The Serrano Cruz case is a very concrete progress and it gives hope and strength to the civil society to continue their efforts to fight against impunity. ${ }^{117}$ This case is only the first step to make the Salvadoran state comply with its obligations according to international law. More cases have to be brought to the Inter-American Court in order to have any influence on the Salvadoran state. Experience has showed that it takes more than one case before states begin to accept their responsibilities and obligations according to international law. ${ }^{118}$

For Pro-Búsqueda and CEJIL the Serrano Cruz case is of significance to make the Salvadoran state comply with its obligations in this particular case as well as contribute to finding the truth about the other cases of disappeared children. Human rights activists also point out that the Serrano Cruz case not only is important for the victims of enforced disappearance of children but for all victims of human rights violations which took place during the armed conflict. All parts of the Salvadoran civil society have high hopes on the Serrano Cruz case and what it will lead to regarding truth, justice and reparation at the national level. ${ }^{119}$

\footnotetext{
${ }^{116}$ Serrano Cruz v. El Salvador, 1 March 2005, paragraph 218

${ }^{117}$ Licenciado Aguilar, PDDH, Seminario Regional "Víctimas y Justicia”, IDHUCA, 12 November 2004

${ }^{118}$ Popkin, Margaret, director of Fundación para el Debido Proceso Legal, Seminario Regional “Víctimas y Justicia”, IDHUCA, 12 November 2004; Interview with Veronica Ardón, lawyer at Pro-Búsqueda, 17 November 2004

${ }^{119}$ Interviews with Victoria Ardón, Pro-Búsqueda 17 November 2004; Gisela de Leon, CEJIL, 1 February 2005; Engracia Chavarría, CPDH, 15 December 2004; Pedro Cruz, IDHUCA, 15 January 2005; Guadalupe Mejía Delgado, CODEFAM, 2 December 2004; Miguel Rogel Montenegro, CDHES, 9 December 2004
} 


\section{International and regional human rights law}

\subsection{Right to an effective remedy and reparation}

In the event of human rights violations there is a right to an effective remedy before domestic authorities and this is laid down in numerous general human rights conventions: article 2(3) ICCPR and article 25 ACHR (See Supplement B) and also in the European Convention on Human Rights and the African Charter. The right to an effective remedy is recognised in the UN Declaration on the Protection of All Persons from Enforced Disappearances (art. 9).

The right to a remedy guarantees a procedural and a substantial claim. At the procedural level states undertake to establish suitable institutions to take decisions on alleged human rights violations. At the substantive level, the right to a remedy means that reparation shall be provided to the victims of human rights violations. It is important that the victims of human rights violations may initiate procedures themselves, since exhaustion of domestic remedies is one of the requirements for admitting international human rights complaints. This conforms to the principle that legal remedy against human rights violations primarily should be ensured at the national level. ${ }^{120}$ The victim's right to a remedy for violations of international human rights includes the right to access justice, which entails all available judicial, administrative or other public processes; adequate, effective and prompt reparation for harm suffered; and access to the factual information concerning the violations. ${ }^{121}$ Regarding the requirement that the remedy should be effective the Inter-American Court has stated that it is not sufficient that a remedy exists, but it must be truly effective in establishing whether there has been a violation of human rights and in providing redress. ${ }^{122}$ The HRC has expressed that complaints concerning human rights violations must be investigated promptly and impartially by competent authorities in order to make the remedy effective. ${ }^{123}$

The distinction between remedy and reparation is that a victim's right to a remedy concerns the availability of avenues to obtain relief from a violation and the right to reparation concerns the particular form and measure of

\footnotetext{
${ }^{120}$ Nowak, Manfred, 2003, p. 63-64

${ }^{121}$ Bassiouni, Cherif M., The Right to Restitution, Compensation and Rehabilitation for Victims of Gross Violations of Human Rights and Fundamental Freedoms, 18 January 2000, E/CN.4/2000/62

${ }^{122}$ Villigrán Morales v. Guatemala, Inter-American Court, 19 November 1999, paragraph 235

${ }^{123}$ HRC General comment No. 20 (44) on article 7
} 
relief. ${ }^{124}$ The different forms of reparation include restitution, compensation, rehabilitation and satisfaction. If restitution is possible, this is the best form of reparation. Restitution means that the situation that existed for the victim prior to the violation of human rights should be re-established. However, in many cases this option is no longer possible and alternative measures of reparation have to be sought, for example compensation for the material and immaterial damage suffered and medical, psychological and social rehabilitation. Another form of reparation is satisfaction which includes cessation of continuing violations; verification of the facts and full and public disclosure of the truth; public apology including acknowledgement of the facts and acceptance of responsibility; commemorations to the victims; guarantees of non-repetition; and changes in the laws etc. Satisfaction for cases of serious human rights violations has increasingly been considered to entail truth commissions, criminal investigations and appropriate penal, civil and disciplinary measures against the individual perpetrator. ${ }^{125}$ There is no legal requirement that all of these forms of reparation should be used, but the form and measure of reparation should be selected in accordance with the principle of proportionality, taking into account the nature of the violation and the harm suffered. The first of these requirements focuses mainly on the perpetrator's conduct, such as the manner in which it was executed, while the second looks at the violation from the victim's perspective, such as the extent of the injuries. ${ }^{126}$

In the context of remedy and reparation it is appropriate to deal with the mechanism in article 63(1) of the ACHR, which establishes the right to "international" reparation in favour of individuals. The provision provides for the possibility that the Inter-American Court directly can require a wrong-doing state to make reparation to the injured individual. ${ }^{127}$ The individual does not appear to have an actual right to reparation on the international level prior to the judgment of the Inter-American Court. The victims of human rights violations have a right to remedy and reparation mostly within their national legal order and only rarely within the international legal order. Moreover, even when individuals obtain a right to reparation through a judgment of the Inter-American Court, their only possibility to actually enforce that right is through the national legal order. ${ }^{128}$ In relation to article 63(1) the Court in the Velásquez Rodríguez

\footnotetext{
${ }^{124}$ Bassiouni, Cherif M., Proposed Guiding Principles for Combating Impunity for International Crimes, Post-conflict Justice, 2002, p. 263

${ }^{125}$ Boven, Theo van, Study concerning the right to restitution, compensation and rehabilitation for victims of gross violations of human rights and fundamental freedoms, Final Report submitted by the Special Rapporteur, 2 July 1993, E/CN.4/SUB.2/1993/8 p. 346

${ }^{126}$ Bassiouni, Cherif M., 2002, p. 265

${ }^{127}$ Article 63(1) of the ACHR: "If the Court finds that there has been a violation of a right or freedom protected by this convention, the Court shall rule that the injured party be ensured the enjoyment of his right or freedom that was violated. It shall also rule, if appropriate, that the consequences of the measure or situation that constituted the breach of such right or freedom be remedied and that fair compensation be paid to the injured party." ${ }^{128}$ Pisillo-Mazzeschi, 'International Obligations to Provide for Reparation Claims?', State Responsibility and the Individual: reparation in instances of grave violations of human
} 
case expressed that it could not order that the victim be guaranteed the enjoyment of the rights or freedoms violated, but that it could rule that the consequences of the breach of the rights be remedied and that just compensation be paid. ${ }^{129}$ The Court decided that the state was required to pay fair compensation to the next-of-kin of the victim and that the form and amount of such compensation, failing agreement within six months of the date of the judgment, was to be settled by the Court. In the judgment on compensatory damages, the scope and content of just compensation was defined. The Court made it clear that as a principle of international law every violation of an international obligation which results in harm creates a duty to make adequate reparation. The Court ruled that reparation "consists in full restitution, which includes the restoration of the prior situation, the reparation of the consequences of the violation and indemnification for damages, including emotional harm”. Punitive damages were excluded. The IACHR maintained that, the Court should order the Honduran government to take some measures, such as the investigation of the facts related to the involuntary disappearance; the punishment of those responsible; a public statement condemning that practice; the revindication of the victim, and other similar measures. In response to this the Court held that it had essentially already ordered these measures in the judgment on the merits, though it made no efforts to determine if the defendant government had complied. The Court also stated that "the judgment on the merits is in itself a type of reparation and moral satisfaction of significance and importance for the families of the victims”. ${ }^{130}$

\subsection{The state's obligations}

\subsubsection{The obligation to guarantee human rights}

International human rights law imposes two categories of obligations on the state: the duty to refrain from violating human rights and the duty to guarantee respect for such rights. The first category comprises those obligations which are directly related to the duty of the state to refrain, by act or omission, from violating human rights, which means ensuring that suitable measures are taken to ensure that such rights can be freely enjoyed. The second category refers to the state's obligations to prevent and investigate violations, bring to justice and punish the perpetrators and provide reparations for harm and injuries caused. Legally speaking, the state is the guarantor of human rights and assumes basic obligations with regard to the protection and safeguarding of such rights. It is on this basis that

rights, 1999, ed. Randelzhofer and Tomuschat, Kluwer Law International: The Hague, pp. 170-171

${ }^{129}$ Velásquez Rodríguez v. Honduras, Inter-American Court, 29 July 1988, paragraph 189

${ }^{130}$ Velásquez Rodríguez v. Honduras, Inter-American Court, 21 July 1989, compensatory damages, paragraphs 25-26, 32-36 and 38 
jurisprudence and legal opinion have developed the concept of the state's duty to guarantee human rights within its jurisdiction. ${ }^{131}$

The duty to guarantee human rights has its legal basis in several human rights treaties. The provisions that are important for this study are article 2(1) of the ICCPR and article 1(1) of the ACHR (see Supplement B), which require states to respect the rights recognised in the conventions and to ensure to all persons within their jurisdiction the free and full exercise of those rights. These provisions implicitly suggest that human rights violations should be investigated and that the victims should be afforded reparation for the wrongs done to them. ${ }^{132}$ The jurisprudence developed by the Inter-American Court, the IACHR and the HRC sees the duty to ensure and guarantee human rights as consisting of five basic obligations which the state must honour: the obligation to investigate, the obligation to bring to justice and punish those responsible, the obligation to provide an effective remedy; the obligation to provide fair and adequate reparation to the victims and their relatives; and the obligation to establish the truth about what happened.

In its first contentious case, the Velásquez Rodríguez case, the InterAmerican Court interpreted article 1(1) in a comprehensive manner. The Court, in relation to the second obligation to ensure rights, stated that "as a consequence of this obligation, the States must prevent, investigate and punish any violations of the rights recognized by the Convention and, moreover, if possible attempt to restore the right violated and provide compensation as warranted for damages resulting from the violations”. In the approach of the Inter-American Court, the obligation to prevent and the obligation to restore are closely interrelated. The Court stated that there is a legal obligation "to take reasonable steps to prevent human rights violations and to use the means at its disposal to carry out a serious investigation of violations committed within its jurisdiction, to identify those responsible, to impose the appropriate punishment and to ensure the victim adequate compensation". ${ }^{133}$

In a case before the IACHR in 1996 it stated that "the duties of the States, to respect and to guarantee, are the cornerstone of the international protection system since they comprise the States' international commitment to limit the exercise of their power, and even of their sovereignty, vis-à-vis the fundamental rights and freedoms of the individual. The duty to respect entails that the States must ensure the effectiveness of all the rights contained in the Convention by means of a legal, political and institutional system appropriate for such purposes. The duty to guarantee, for its part,

\footnotetext{
${ }^{131}$ Article concerning the legality of amnesty laws: Argentina: legal memorandum on the Full Stop and the Due Obedience Laws submitted by Amnesty International and the International Commission of Jurists, 26 February 2004, http://www.icj.org/ news.php3?id article=3246\& lang=en, 2005-03-15

${ }^{132}$ O'Shea, Andreas, Amnesty for Crime in International Law and Practice, 2002, pp. 271272

${ }^{133}$ Velásquez Rodríguez v. Honduras, Inter-American Court, 29 July 1988, paragraphs 165166 and 174
} 
entails that the States must ensure the effectiveness of the fundamental rights by ensuring that the specific legal means of protection are adequate either for preventing violations or else for re-establishing said rights and for compensating victims or their families in cases of abuse or misuse of power." 134 Recently the IACHR stated that "In accordance with human rights treaties, states must respect and ensure the human rights of all persons under their jurisdiction. They are therefore obligated to investigate and punish any violation of these rights, especially when such violations also constitute crimes under international law."135

The obligations mentioned in this chapter, which make up the state's duty to guarantee human rights, are by their very nature complementary and are not alternatives or substitutes for each other. Although they can be fulfilled separately, this does not mean that the state is not obliged to fulfil each and every one of them. The separate and independent character of each obligation that makes up the duty to guarantee human rights has been reaffirmed repeatedly by the Inter-American Court. The Court has pointed out that a waiver by a victim of human rights violations of his entitlement to compensation does not mean that the state is released from its obligation to investigate the case and to try and punish the perpetrators. In the Court's view, "even though the aggrieved party may pardon the author of the violation of his human rights, the State is nonetheless obliged to sanction said author... The State's obligation to investigate the facts and punish those responsible does not erase the consequences of the unlawful act in the affected person. Instead, the purpose of that obligation is that every State party ensure, within its legal system, the rights and freedoms recognized in the Convention." 136 The IACHR has on repeated occasions stated that neither the granting of compensation to victims and their relatives, nor the establishment of truth commissions, in any way relieves the State of its obligation to bring those responsible for human rights violations to justice and to ensure that they are punished. In the case of El Salvador, the IACHR pointed out that, despite the important role played by the Truth Commission in establishing the facts surrounding the most serious violations and in promoting national reconciliation, a commission of this type can not "be accepted as a substitute for the State's obligation, which cannot be delegated, to investigate violations committed within its jurisdiction, and to identify those responsible, punish them, and ensure adequate compensation for the victim."

The HRC to a larger extent than the Inter-American Court and the IACHR derives the obligation of states to take action on alleged human rights violations from the duty to provide an effective remedy (see next chapter), but it seems clear that the obligation to ensure the rights contained in the

\footnotetext{
${ }^{134}$ Chumbivilcas v. Peru, IACHR, Report no. 1/96, 1 March 1996

135 IACHR Resolution N 1/03, On Trial for International Crimes, 24 October 2003

${ }^{136}$ Garrido and Baigorria v. Argentina, Inter-American Court, 27 August 1988, compensatory damages, paragraph 72

${ }^{137}$ Ignacio Ellacuría S.J and others v. El Salvador, IACHR, Report No. 136/99, 22 December 1999, paragraph 230
} 
ICCPR also plays an important role. In the mid 90's the HRC, in individual communications, started to refer to article 2(1) of the ICCPR and the obligation to ensure the rights recognised in the Covenant. This is done in connection to statements about the state's obligations to take certain action on alleged violations. ${ }^{138}$

\subsubsection{The obligation to provide an effective remedy}

As stated in chapter 6.1, the right to an effective remedy and judicial protection is embodied in numerous human rights instruments. Article 2(3) of the ICCPR is more specific than the "ensure and respect" provision since it indicates in concrete terms that the victims should be afforded reparation for the harm suffered by human rights violations, through having access to an effective remedy. The ICCPR does not mandate a state party to pursue a specific course of action to remedy the violation of protected rights, but the provision clearly envisions that the remedy should be effective, which normally would require, in addition to a thorough investigation, access to court and fair compensation. ${ }^{139}$ The right to an effective remedy is intended to ensure that a victim has a fair forum to present and pursue a claim that is free from unreasonable impediments and procedures that might foreclose a particular avenue. If a fair and free forum does not exist, the state must establish a new remedy to meet the concerns of the particular circumstances. Not only must states provide remedies that victims may pursue, but they must also ensure that victims are fully aware of their options and how to take advantage of them. ${ }^{140}$

As stated in the previous chapter, the state should guarantee human rights within its territory and the duties to prevent and investigate violations, bring to justice and punish the perpetrators and provide reparation derive from this obligation. Therefore, the state is obliged to provide victims, whose rights have been violated by private persons, with an effective remedy. This conclusion can also be drawn explicitly from the effective remedyprovisions of the ICCPR and the ACHR. Both provisions state that persons whose rights have been violated have the right to an effective remedy, even though the violation has been committed by persons acting in an official capacity. This shows that victims of violations committed by private persons have a right to an effective remedy, which the state must provide. However, in such cases where the violation is not attributable to the state, the responsible party should provide reparation to the victim, or to the state, if the state has already provided the victim with reparation. The obligation of the state in these cases is to provide victims with recourse, not reparation. ${ }^{141}$

\footnotetext{
${ }^{138}$ Vicario v. Argentina, HRC, 27 April 1995, paragraph 11.3; Bautista v. Colombia, HRC, 13 November 1995, paragraph 11; Laureano v. Peru, HRC, 16 April 1996, paragraph 11

${ }^{139}$ O'Shea Andreas, 2002, pp. 271-272

${ }^{140}$ Bassiouni, Cherif M., 2002, p. 263

141 ibid. p. 264
} 
The HRC has repeatedly stressed that state parties must comply with the fundamental obligation under article 2(3) to provide a remedy that is effective. The HRC, in addition to stating that state parties are under an obligation to take effective measures to remedy violations, has spelled out specific types of remedies that are called for, depending on the nature of the violation and the condition of the victim. It has expressed the view that states are under an obligation to investigate serious violations; take appropriate action; bring to justice those who are found responsible; and to provide reparation to victims or to his or her family. ${ }^{142}$

The Inter-American Court has expressed that state parties have an "obligation to provide effective judicial remedies to victims of human rights violations (art. 25 of the ACHR), remedies that must be substantiated in accordance with the rules of due process of law (art. 8(1)), all in keeping with the general obligation of such States to guarantee the free and full exercise of the rights recognized by the Convention to all persons subject to their jurisdictions." ${ }^{143}$ In accordance with this advisory opinion, the Court in the Villigrán Morales case stated that "everyone has the right to a simple and prompt recourse, or any other effective recourse, to a competent court or judge for protection against acts that violate his fundamental rights, which constitutes one of the basic pillars not only of the American Convention, but also of the very rule of law in a democratic society in the sense of the Convention". The Court further stated that article 25 assigns "duties of protection to the States Parties through their domestic legislation, from which it is clear that the State has the obligation to design and embody in legislation an effective recourse, and also to ensure the due application of the said recourse by its judicial authorities."144

\subsection{Enforced disappearances}

\subsubsection{In general}

The practice of enforced disappearances is a fairly recent phenomenon which was "invented" in Nazi-Germany and reappeared in Latin America in the late 1960's. In many Latin American countries the systematic practice of enforced disappearances constituted a part of the governments' strategy to oppress what was seen as their enemy according to the doctrine of national security. The term "enforced disappearance" was first used by Latin

\footnotetext{
${ }^{142}$ Boven, Theo van, Study concerning the Right to Restitution, Compensation and Rehabilitation for Victims of Gross Violations of Human Rights and Fundamental Freedoms, Final Report submitted by the Special Rapporteur, 2 July 1993, E/CN.4/SUB.2/1993/8, pp. 310-311

${ }^{143}$ Advisory Opinion OC-9/87 of 6 October 1987, Judicial Guarantees in States of Emergency (arts. 27.2, 25 and 8 American Convention on Human Rights), Series A, Judgments and Opinions No. 9 (1987), paragraph 24

${ }^{144}$ Villigrán Morales v. Guatemala, Inter-American Court, 19 November 1999, paragraphs 234 and 237
} 
American NGO:s and is a translation of the Spanish expression “desaparición forzada". The IACHR and the UN Commission on Human Rights were the first international human rights bodies to react on the practice of enforced disappearance in Latin America, when they responded to the Chilean situation after the military coup in 1973. Since then enforced disappearances has become a universal problem. The UN Working Group on Enforced or Involuntary Disappearances was established 1980 and El Salvador is one of the countries with the highest number of reported cases. $^{145}$

There are no universal conventions regarding this issue, but since enforced disappearances were widespread in Latin America, OAS concluded an InterAmerican Convention on the Forced Disappearance of Persons in $1994{ }^{146}$ Article II defines enforced disappearances as "the act of depriving a person or persons of his or their freedom, in whatever way, perpetrated by agents of the State or by persons or groups of persons acting with the authorisation, support or acquiescence of the State, followed by an absence of information or a refusal to acknowledge that deprivation of freedom or to give information on the whereabouts of that person, thereby impeding his or her recourse to the applicable legal remedies and procedural guarantees". There is also a non-binding UN Declaration ${ }^{147}$ and a draft of an international convention ${ }^{148}$ on the issue of enforced disappearances.

An enforced disappearance is a complex and cumulative violation of several fundamental human rights. This is confirmed both in the Inter-American Convention on the Forced Disappearance of Persons, the UN Declaration and the convention draft, as well as in case law from the HRC and the InterAmerican Court. The relevant rights in the ICCPR are: the right to life (art. 6 ); the prohibition of torture, cruel, inhuman or degrading treatment or punishment (art. 7); the right to liberty and security of person (art. 9); the right of detainees to be treated with humanity and respect for the dignity (art. 10); and the right to recognition as a person before the law (art. 16). The following provisions of the ACHR have proved to be relevant in disappearance cases: the right to juridical personality (art.3); the right to life (art. 4); the right to humane treatment (art. 5); the right to personal liberty and security (art. 7); the right to a fair trial (art. 8). The Inter-American Court has expressed that "forced or involuntary disappearances is one of the most cruel human rights violations, in that it not only produces arbitrary deprivation of freedom but places the physical integrity, security and the very life of the detainee in danger. It also leaves the detainee utterly defenceless, bringing related crimes in its wake”. ${ }^{149}$

\footnotetext{
145 Nowak, Manfred, Report on Civil and Political Rights, Including Questions of: Disappearances and Summary Executions, 8 January 2002, E/CN.4/2002/71, pp. 7-8

146 The Inter-American Convention on the Forced Disappearance of Persons, 6 September 1994, came into force 1996. Eight countries have ratified it, but El Salvador is not one of these.

${ }^{147}$ Approved by the General Assembly of the UN, resolution 47/133, 18 December 1992

${ }^{148}$ Draft International Convention on the Protection of all Persons from Forced Disappearance [E/CN.4/Sub.2/1998/19, Annex] (1998)

${ }^{149}$ Blake v. Guatemala, Inter-American Court, 24 January 1998, paragraph 66
} 


\subsubsection{Enforced disappearance of minors}

Concerning the abduction of minors, the concept of enforced disappearance has to be somewhat reconsidered. The Inter-American Convention on the Forced Disappearance of Persons mentions the abduction of children, but only in connection with the enforced disappearance of the parents. ${ }^{150}$ The UN Declaration, like the Inter-American Convention, deals with the abduction of children of parents subjected to enforced disappearance and also the abduction of children born during their mother's enforced disappearance. ${ }^{151}$ Article 18 of the draft convention addresses one of, what it considers, the most serious aspects of enforced disappearances, namely, the abduction of children and their subsequent adoption.

In contrast to the enforced disappearance of an adult, where a disappearance followed by a lack of information after a period of years can create a reasonable presumption that the individual has been killed, abducted minors are usually given up for adoption or are held at institutions. At least this is so when younger children are abducted. However, every enforced disappearance poses a great threat to the right to life, which is why this article is also relevant in cases concerning minors. In addition, as in the case with adult disappearances, the right to liberty and security is violated, even though the abducted children usually are not de facto held in detention, they are deprived of their freedom through the abduction and the subsequent happenings. ${ }^{152}$

What distinguishes the enforced disappearance of children is that it violates the child's right to an identity, including nationality, name and family relations. In the case of the disappearance of an Argentinean child before the HRC, it was established that the abduction, the falsification of the birth certificate and the adoption entailed numerous acts of arbitrary and unlawful interference with the child's and family's privacy and family life, in violation of article 17 of the ICCPR. These events were also held to be in violation of article 23(1), which protects the family unit, article 24(1) and (2) which recognise the right of every child to special measures of protection, including the recognition of the child's legal personality. In this case the abducted child had been found at the age of seven and the delay in legally establishing the child's real name and issuing identity papers also entailed a violation of article $24(2)$ of the ICCPR. ${ }^{153}$ The Inter-American Court has also confirmed that the rights of the child (art. 19) are violated in cases where children are abducted. ${ }^{154}$

\footnotetext{
${ }^{150}$ Article XII of the Inter-American Convention

${ }^{151}$ UN Declaration on the Protection of All Persons from Enforced Disappearance, Article 20, para. 1

152 Nowak, Manfred, 2002, pp. 28-29

${ }^{153}$ Vicario v. Argentina, HRC, no. 400/1990, 27 April 1995, paragraphs 10.4 and 10.5

${ }^{154}$ Villigrán Morales v. Guatemala, Inter-American Court, 19 November 1999, paragraph 198
} 


\subsubsection{The victims}

The crime of enforced disappearance is not only directed against the person who disappears, but equally against their families, friends and the society in which they live. In the case of abducted children, their parents and families continue to live in a situation of extreme insecurity, anguish and stress, torn between hope and despair. ${ }^{155}$ An enforced disappearance can thus be seen as a form of inhuman and degrading treatment for the parents. The HRC decided in 1983 that "the anguish and stress caused to the mother by the disappearance of her daughter and by the continuing uncertainty concerning her fate and whereabouts" rendered her a victim of violations of the ICCPR, in particular article 7 (torture, inhuman and degrading treatment). ${ }^{156}$ The mother had the right to know what had happened to her daughter and in this respect the mother too was a victim of the violations suffered by her daughter. The Inter-American Court has recognised that "the circumstances of such disappearance generate suffering and anguish, in addition to a sense of insecurity, frustration and impotence in the face of the public authorities' failure to investigate", which justified considering the family members as victims of inhumane treatment according to article 5(2) of the ACHR. The Court also ruled that the right to a fair trial (article 8) recognised the right of the relatives to have the disappearance and the death effectively investigated by the authorities, but the right to judicial protection (art. 25) could not be applied since the family of the disappeared person had not tried to initiate any judicial action, such as the remedy of habeas corpus. ${ }^{157}$ In the Villigrán Morales case, the Court found that the rights in articles 5(2), 8 and 25 had been violated not only for the abducted persons but also to the detriment of their immediate next of kin. ${ }^{158}$

\subsubsection{Enforced disapperances and state obligations}

Regarding the right to a remedy and judicial protection in connection to enforced disappearances, one can rely on case law provided by the HRC, the IACHR and the Inter-American Court.

\subsubsection{The ICCPR}

Under the optional protocol to the ICCPR, the HRC may receive and consider communications from individuals who claim to be victims of a violation of the rights recognised in the Covenant by a state party. When the HRC has found that a provision of the ICCPR has been violated, it usually proceeds to urge the state party to take appropriate action to remedy the

\footnotetext{
${ }^{155}$ Nowak, Manfred, 2002, p. 4

${ }^{156}$ Quinteros v. Uruguay, HRC, no. 107/1981, 21 July 1983, paragraph 14

${ }^{157}$ Blake v. Guatemala, Inter-American Court, 24 January 1998, paragraphs 97, 104 and 114-116

${ }^{158}$ Villigrán Morales v. Guatemala, Inter-American Court, 19 November 1999, paragraphs 172-177 and 238
} 
violation. The HRC has in several communications dealt with cases regarding enforced disappearances and discussed the victims' right to a remedy and the state's obligation to provide for it.

In the Bleier case, which was the first communication concerning an enforced disappearance, the HRC stated that besides violations of articles 7 , 9 and 10(1) of the ICCPR there were serious reasons to believe that the ultimate violation of article 6 had been perpetrated by the Uruguayan authorities. Concerning that latter point, the HRC urged the government to reconsider its position and take effective steps to establish what had happened to Bleier since he disappeared, to bring to justice any persons found to be responsible for his death, disappearance or ill-treatment, and to pay compensation to Bleier or his family for any injury which he had suffered. The HRC also urged that the state should ensure that similar violations did not occur in the future. ${ }^{159}$ Implicit in the HRC's decisions is the view that investigation and prosecution are the most effective means of securing the right not to become a victim of enforced disappearance. In view of the importance that the HRC has attached to the right to life and the right to be free from torture and enforced disappearance, it is reasonable to assume that state parties are obligated to use the most effective means available to ensure the enjoyment of these rights. ${ }^{160}$

The question of an effective remedy was further developed in the Bautista case where the HRC said that in the event of particularly serious human rights violations "purely disciplinary and administrative remedies cannot be deemed to constitute adequate and effective remedies within the meaning of article 2(3) of the ICCPR.” In this case a Colombian administrative tribunal had granted the claim for compensation filed by the victim's family, and disciplinary sanctions were pronounced against two military intelligence officers. Obviously, the HRC did not consider these measures to satisfy the victim's right to an effective remedy. The HRC further held that the ICCPR does not provide a right for individuals to require that the state criminally prosecute another person, but it nevertheless considered that "the State party is under a duty to investigate thoroughly alleged violations of human rights, and in particular forced disappearances and violations of the right to life, and to prosecute criminally, try and punish those held responsible for such violations". The HRC urged the state to expedite the criminal proceedings leading to the prompt prosecution and conviction of the persons responsible for the abduction, torture and death of the victim. ${ }^{161}$

In the Laureano case, which concerned the enforced disappearance of a minor, the HRC urged the Peruvian state to provide the victim with an effective remedy similar to that in the Bleier case, which would consist of a proper investigation, compensation to the victim and her family and

\footnotetext{
${ }^{159}$ Bleier v. Uruguay, HRC, no. 30/1978, 29 March 1982 paragraphs 14-15

${ }^{160}$ Orentlicher, Diane, 'Settling Accounts: The Duty to Prosecute Human Rights Violations of a Prior Regime’, Yale Law Journal, 1991, vol. 100, pp. 2575-2576

${ }^{161}$ Bautista v. Colombia, HRC, no. 563/1993, 13 November 1995, paragraphs 8.2, 8.6 and 10
} 
bringing to justice those responsible, notwithstanding any domestic amnesty legislation to the contrary. ${ }^{162}$ In the well-known case of an Argentinean child (see chapter 6.3.2), the HRC as a remedy explicitly encouraged the government to "persevere in its efforts to investigate the disappearance of children, determine their true identity, issue to them identity papers and passports under their real name, and grant appropriate redress to them and their families in an expeditious manner". ${ }^{163}$

\subsubsection{The ACHR}

In cases involving violations of the right to life, liberty and personal security the IACHR has repeatedly recommended that the offending state order a thorough and impartial investigation and, in accordance with domestic law, punish the individual or individuals responsible. It has similarly recommended that state parties to the ACHR investigate serious violations of physical integrity and that they try to punish those responsible, as well as provide victims with compensation. ${ }^{164}$

As already has been stated, the Inter-American Court interprets the obligation contained in article 1(1) of the ACHR in a comprehensive manner (see chapter 6.2.1). In the Velásquez Rodríguez case the Court urged the state to use all means at its disposal to carry out a serious investigation, to identify and punish those responsible and to ensure victims compensation. ${ }^{165}$ The Court's view on what remedy states are obliged to provide in disappearance cases has been further developed in the Blake case. The Court ruled that the right to a fair trial (art. 8 of the ACHR) "recognises the rights of Mr. Blake's relatives to have his disappearance and death effectively investigated by the Guatemalan authorities; to have those responsible prosecuted for committing said unlawful acts; to have the relevant punishment, where appropriate, meted out; and to be compensated for the damages and injuries they sustained". In the judgment the Court declared that Guatemala was obliged to use all means at its disposal to investigate the acts denounced and punish those responsible for the disappearance and death of the victim and ordered the state to pay a fair compensation to his relatives. ${ }^{166}$

In the Villigrán Morales case, which concerned the disappearance of Guatemalan street children, the Court discussed the obligations of the state in relation to articles 8 and 25. The Court stated that "it is clear from Article 1(1) that the State is obliged to investigate and punish any violation of the rights embodied in the Convention in order to guarantee such rights; and, in the circumstances of the instant case, this obligation is related to the rights to be heard by the courts and to a prompt and effective recourse, established in Articles 8 and 25 of the Convention”. The Court judged that the state had

\footnotetext{
${ }^{162}$ Laureano v. Peru, HRC, no. 540/1993, 16 April 1996, paragraph 10

${ }^{163}$ Vicario v. Argentina, HRC, no. 400/1990, 27 April 1995, paragraph 12

164 Orentlicher, Diane, 1991, pp. 2578-2579

165 Velásquez Rodríguez v. Honduras, Inter-American Court, 29 July 1988, paragraph 174

${ }^{166}$ Blake v. Guatemala, Inter-American Court, 24 January 1998, paragraphs 97 and 124
} 
violated article 1(1) according to which it was obliged to conduct a real and effective investigation to determine the persons responsible for the human rights violations referred to in the judgment and eventually punish them. The Court also ordered that the phase of reparations should be opened. ${ }^{167}$

\subsection{The legality of amnesty laws under human rights law}

Both the ICCPR and the ACHR are textually silent about the duty to prosecute and punish violations of the rights they are designed to protect. The obligation to bring the perpetrators of gross violations of human rights to justice, as an expression of the duty to guarantee human rights, instead derives legal force from article 2(1) of the ICCPR and article 1(1) of the ACHR (see chapter 6.2.1). This obligation is also related to the right of every person to an effective remedy and judicial recourse, which is enshrined in article 25 of the ACHR and article 2(3) of the ICCPR (see chapter 6.2.2). ${ }^{168}$

\subsubsection{The position of of the HRC}

The issue of amnesty was addressed by the HRC at an early stage, responding to the Chilean amnesty law of 1978, when the HRC questioned the validity of applying the amnesty to any person responsible for gross violations of human rights, particularly enforced disappearance. In its general comment on article 7 of the ICCPR, the HRC concluded that: "Amnesties are generally incompatible with the duty of States to investigate such acts; to guarantee freedom from such acts within their jurisdiction; and to ensure that they do not occur in the future. States may not deprive individuals of the right to an effective remedy, including compensation and such full rehabilitation as may be possible". The HRC has repeatedly reaffirmed this precedent when examining amnesties passed by states parties to the ICCPR. For example, in its concluding observations to the state report of El Salvador, the HRC expressed its "concern at the General Amnesty Law of 1993 and the application of that Law to serious human rights violations, including those considered and established by the Truth Commission. [...] the Committee considers that the Law infringes the right to an effective remedy set forth in article 2 of the Covenant, since it prevents the investigation and punishment of all those responsible for human rights violations and the granting of compensation to the victims." The HRC went on to recommend that the Salvadoran authorities amend the amnesty law to

\footnotetext{
${ }^{167}$ Villigrán Morales v. Guatemala, Inter-American Court, 19 November 1999, paragraphs 225 and 253

${ }^{168}$ Sharf, Michael, 'The Letter of the Law: the Scope of the International Legal Obligation to Prosecute Human Rights Crimes', Law and Contemporary Problems, vol. 59, issue 4, 1996, p. 49-50
} 
make it compatible with the ICCPR and that the state party should respect and guarantee the application of the rights enshrined in the Covenant. ${ }^{169}$

In the Rodríguez case, the HRC held that Uruguay's amnesty law violated the right to an effective remedy under the ICCPR by ultimately excluding in a number of cases the possibility of investigation into past human rights violations and thereby preventing the state from fulfilling its responsibility to provide effective remedies to the victims. ${ }^{170}$

\subsubsection{The position of the Inter-American System}

Since impunity and amnesty laws have been so widespread throughout the Latin American continent, the IACHR and the Inter-American Court have in various cases considered the international legality of amnesty laws in transitional societies. In 1986 the IACHR gave a tentative opinion on the international legal status of amnesty laws. It said that in principle states should determine the question of amnesties having regard to their special need to reconcile the nation. The IACHR did however recognise the right of the families of victims to know the truth and the Commission considered that states are under a duty to investigate past human rights violations. ${ }^{171}$

When studying the Inter-American jurisprudence on the legality of amnesty laws one has to start with the Velásquez Rodríguez case. This case did not directly concern the legality of amnesty laws, but it gave the legal foundation for future challenges before the IACHR - the Inter-American Court gave the impetus for condemning amnesty laws. In a series of decisions the IACHR has developed a fairly consistent view on the question of the international legality of transitional amnesty laws. ${ }^{172}$ In Consuelo et al. v. Argentina ${ }^{173}$ the IACHR considered whether violations of the ACHR had occurred as a result of the fact that several amnesty law had been passed in Argentina. The Commission held Argentina to have violated the petitioners' right to a fair trial under article 8(1) read in the light of article 1(1) when it denied their right to recourse, to a thorough and impartial judicial investigation to ascertain the facts. The IACHR also found article 25 of the ACHR to have been violated without analysing the applicability of the article to the situation. It further held that Argentina had violated its obligation to ensure the free and full exercise of the rights recognised by the ACHR in terms of article 1(1), citing the statements of the Inter-American Court in the Velásquez Rodríguez case.

\footnotetext{
${ }^{169}$ Concluding Observations of the HRC: El Salvador, UN document CCPR/CO/78/SLV, 22 August 2003, paragraph 6

${ }_{170}$ Rodríguez v. Uruguay, HRC, no. 322/1988, 9 August 1994, paragraph 12.4

${ }^{171}$ Amnesty laws: the Opinion of IACHR, Annual Report, 1985-86, OEA/SER. L/V/11. 68

${ }^{172}$ O'Shea, Andreas, Amnesty for Crime in International Law and Practice, 2002, pp. 6465

${ }^{173}$ Consuelo et al. V. Argentina, IACHR, Report no. 28/92, 2 October 1992, paragraphs 37, 39 and 41
} 
In Masacre Las Hojas v. El Salvador, the IACHR found that the 1987 amnesty law violated article 1(1) and the right to judicial protection under article 25 of the ACHR. It further pointed out that the protection of the right to life and the right to personal integrity in articles 4 and 5 are nonderogable rights and that article 27 of the ACHR prohibits the suspension of guarantees indispensable to the protection of non-derogable rights. The IACHR stated that article 27 of the Vienna Convention on the Law of Treaties prohibits a state from invoking national law as a justification for failing to comply with legal obligations imposed upon it. ${ }^{174}$

In the case of Lucio Parada v. El Salvador the IACHR examined the Salvadoran amnesty law of 1993. Articles 8, 25 and 1(1) were held to have been violated. The IACHR also stated that "in expressly eliminating all civil liability, this law prevented the surviving victims and those with legal claims on behalf of Lucio Parada and Héctor Miranda Marroquín from access to effective judicial recourse and a decision on their possible efforts to seek civil compensation". ${ }^{175}$

\footnotetext{
${ }^{174}$ Masacre Las Hojas v. El Salvador, IACHR, Report no. 26/92, 24 September 1992

${ }^{175}$ Lucio Parada v. El Salvador, IACHR, Report no. 1/99, 27 January 1999, paragraph 128
} 


\section{Analysis and conclusions}

Before analysing the rights of the victims and the obligations of the Salvadoran state in the light of international law, some general conclusions will be drawn. First, there can be no doubt that hundreds of Salvadoran children were involuntary separated from their families during the armed conflict, thereby becoming victims of enforced disappearance. Neither can there be any doubt that the abduction of children constituted a systematic practice of military units connected to the state as a mean to fight the guerrilla and it can not be denied that the FMLN was responsible for the disappearance in some cases. However, international human rights law keeps to the traditional notion that only direct and indirect state actors are capable of committing the human rights violation of enforced disappearance. This is reflected in the practice of the Working Group on Enforced or Involuntary Disappearances, as well as in the definitions of enforced disappearance contained in the Inter-American Convention on the Forced Disappearance of Persons, the UN Declaration and the draft convention.

The abduction of children violates several fundamental provisions in the ICCPR and the ACHR. Case law of the HRC, the IACHR and the InterAmerican Court has interpreted enforced disappearances to violate human rights such as the right to life; the right to liberty and security; the prohibition of torture, cruel or inhuman treatment; the right to recognition as a person before the law; and since this study concerns abduction of children, the right of children to special measures of protection and their right to an identity.

\subsection{Obligations of El Salvador}

In general terms, the obligations of the state are to guarantee human rights within its territory and provide victims with an effective remedy when their rights according to international human rights law have been violated. These obligations are clear under both the ICCPR and the ACHR, to which El Salvador is a state party. However, the difference is that when a violation of a right contained in the ICCPR or the ACHR has occurred, the HRC tends to rely more on the obligation to provide an effective remedy and the IACHR and the Inter-American Court rely more on the obligation to guarantee rights in order to determine what action the state should take.

So, what are the obligations of El Salvador regarding the enforced disappearance of children, which constitutes a violation of human rights and has been committed within its jurisdiction? As pointed out above, non-state actors, such as the FMLN, can not commit the crime of enforced disappearance. However, this does not mean that the Salvadoran state does not have certain obligations towards the victims of human rights violations 
committed by private persons. It can be concluded that where the human rights of a person within the jurisdiction of El Salvador have been violated, either by a state-agent or by a private person, the state has an obligation to provide the victim with an effective remedy within the national legal system. Thus, in this case both victims of the practice of the armed forces and victims of FMLN-abductions should be guaranteed their human rights and be afforded with an effective remedy by the Salvadoran state.

The two general obligations to guarantee human rights and to provide an effective remedy give rise to certain duties, which the state must comply with. This has been developed through the jurisprudence of the HRC, the IACHR and the Inter-American Court, since the ICCPR and the ACHR do not express explicitly what action the state has to take when responding to human rights violations. The state's duties are to investigate, bring to justice and punish those responsible; to provide reparation to the victims; and to establish the truth. In other words, the state is obliged to provide the victims of human rights violations with truth, justice and reparation.

Regarding the victims of enforced disappearance of minors this implies that they should be able to denounce the violations of human rights to the Salvadoran authorities, who then are obliged to carry out serious investigations. If the responsible person (or persons) is found in these investigations, he or she should be prosecuted and punished according to the national legal order. Since an enforced disappearance is a particularly serious human rights violation, disciplinary and administrative remedies do not satisfy the state's obligation to provide a remedy that is effective. The victims, which include the families of the abducted children, should be provided with access to the truth about what happened, both about the abduction and the subsequent happenings. This obligation could be realised by a national search commission. Finally, the victims should be provided with fair reparation. In the cases where children were abducted by the armed forces of the government it is clear that the Salvadoran state is obliged to provide for this. In the cases where persons within the FMLN were involved, the state must ensure that the victims have access to a fair forum where they can present and pursue a claim for reparation.

When dealing with the concept of fair reparation, which should be adequate, effective and prompt, the principle of proportionality is important. This means that the measure of reparation should be selected taking into account the nature of the violation and the harm suffered. Since an enforced disappearance is considered to violate several fundamental human rights contained in the ICCPR and the ACHR, it must be held that enforced disappearances are of a grave nature. In addition, as stated in the draft convention on the enforced disappearance of persons, abduction of children and their subsequent adoption is one of the most serious aspects of enforced disappearances. Looking at the perpetrators' conduct, this does not make the nature of the violations less grave, at least concerning the conduct of the armed forces of the government, where children usually were abducted during cleansing operations where the civil population was indiscriminately 
attacked. Regarding the harm suffered by the victims, it can be concluded that it has been extensive, both for children and families, and can be said to be of a moral nature. The next step is to see what form of reparation the victims are entitled to at the national level.

Many of the principles relating to the right of reparation in cases of enforced disappearance are in the process of being developed by case law of monitoring bodies and courts and in the framework of the UN Human Rights Commission's principles and guidelines. Therefore, it can not be said that the precise content of the right to reparation yet is established in international law. The drafting of a legally binding instrument on enforced disappearances might contribute to the concept of right to reparation. However, some conclusions regarding reparation for the enforced disappearance of children can be drawn, having the principle of proportionality in mind. Regarding restitution, those children, now adults, who are found should have the right to have the true identity determined and be issued identity papers and passports under their real name. However, in many cases the abducted children have built up new lives with new identities, which make restitution meaningless. Of course, family reunions should be promoted in those cases where the child has been found, but the fact remains: what was taken away from the children - their identity - can not be given back to the victims just like that.

In order to provide victims with adequate reparation, it is clear from case law that compensation plays an important part. Compensation should be provided for any damage resulting from the abduction. Therefore, in cases of enforced disappearance of minors, effective reparation should include compensation for the mental suffering and pain of the children and their families. It is not an easy task to determine the compensation, because it can never replace what has been lost, since the harm done to the victims is not material, but moral. Rehabilitation is one of the forms of reparation and in the case of disappeared children, what should be a part of any meaningful reparation is psychological care, mainly for found children but also for their families, as well as legal and social services.

Severe human rights violations, such as the enforced disappearance of children, especially those that are part of a systematic pattern, understandably arouse demands for more than simply compensation. Therefore, in order to provide the victims with adequate reparation, it is necessary with some measures of satisfaction. Satisfaction is a very broad category of reparations and some of the measures of satisfaction are already part of what constitutes an effective remedy, such as the establishment of the truth, including the fate and the whereabouts of the disappeared children, and measures against individual perpetrators. In this case the victims should have a full and public disclosure of the truth about the practice of abducting children. In the cases where the FMLN was involved, the truth should be revealed about the facts that led to that children were brought to so called "houses of security". The victims should also be afforded an official apology, including acceptance of responsibility. Furthermore, guarantees of 
non-repetition should be given and the victims' sufferings should be remembered in special commemorations and tributes, which could take the form of a monument and/or a national day.

\subsection{Is El Salvador in breach of its obligations?}

The obligations El Salvador has to fulfil according to international law in respect of the victims of enforced disappearance of minors have been established in the previous chapter and I will now turn to the question of whether El Salvador is in breach of these obligations and what the consequences might be.

Regarding the obligation to provide the victims with the truth, this has not been taken seriously by the Salvadoran state. The first chance for the victims to have some sort of over-all truth about what happened to the abducted children came with the Truth Commission. However, its report did not contribute to finding truth for this specific group of victims. To the contrary, they were the ignored victims of the armed conflict. The Interinstitutional Search Commission created by the Salvadoran government does not seem to have been established as a sincere effort to find out the truth, but rather as a mechanism of protection before the Inter-American Court. So far it has not reached any results and it will most likely not do so, partly because the state still does not admit that children were subject to enforced disappearances because of the state's strategy to fight the guerrilla and partly because the civil society is not involved in the work of the commission. It is only thanks to the efforts of Pro-Búsqueda that the truth has been revealed in some cases.

When it comes to justice in the sense of conducting serious criminal investigations, bringing those found responsible to justice and punish them according to the law, the Salvadoran state has failed once again. The broad amnesty law of 1993 effectively hinders that justice is being done. The law is clearly contrary to the obligations to guarantee human rights and provide an effective remedy and is justified through a misinterpretation of international humanitarian law. The impunity works from governmental level and down to the judiciary which makes it extremely hard to have the cases properly investigated. The Serrano Cruz case is illustrative, showing what the situation for the victims is like. The lower court does not conduct a proper investigation and the remedy of habeas corpus does not give any result. It has even gone so far, that the authorities are trying to prove the inexistence of the sisters. This means that the Salvadoran state has not ensured that the victims have had access to a fair forum, where they could present their claims, which is in violation of international and regional human rights law. 
When the victims are being denied truth and justice, the prospects for obtaining reparation are minimal. The Salvadoran state completely ignored the Truth Commission's proposal of a compensation scheme and the amnesty law also bars civil claims. All measures of satisfaction seem far away since the government does not admit their responsibility concerning the disappeared children, which makes it unlikely that an official apology will be given.

In conclusion, the Salvadoran state has breached its obligations according to the ICCPR and the ACHR to guarantee human rights within its territory and provide the victims of the enforced disappearance of children with an effective remedy, in the form of truth, justice and reparation. Impunity for past human rights violations, to the detriment of the victims of the enforced disappearance of children, has prevailed in the Salvadoran society ever since the conflict ended.

So, what can this refusal to comply with its obligations according to international law lead to for the Salvadoran state? It means that El Salvador can be held internationally responsible. In this case it is the Inter-American Court that can judge on the question of responsibility of the Salvadoran state and that is what the Court has done in the Serrano Cruz case. It stands clear that El Salvador is in breach of its obligations according to the ACHR and there are no problems of attributing the unlawful acts or omissions to the Salvadoran state, since the state should be the guarantor of human rights within its territory and provide effective remedies to victims. These obligations can not fall on anyone else but the state itself. Consequently, the Salvadoran state can be held responsible for not complying with its international obligations. A judgment of the Inter-American Court, establishing state responsibility, does not have many implications for the victims at the national level, except for the family of the Serrano Cruz sisters, which will obtain international reparation according to article 63(1) of the ACHR. However, even when individuals obtain a right to reparation through the Inter-American System of Human Rights, they only have the possibility to enforce that right on the national level. (See more in chapter 7.4).

\subsection{Why does El Salvador not comply with international law?}

It is obvious in this study that the Salvadoran state has not acted in accordance with its obligations according to international human rights law. Not only has it failed in its respect for human rights, it has also denied the victims of the enforced disappearance of children access to an effective remedy, thereby failing to guarantee these rights.

The systematic practice of abducting children during the armed conflict was not mentioned in the report of the UN Truth Commission, leaving the 
victims with a sense that their sufferings had not been recognised. Since the enforced disappearance of children was not mentioned in the STC's report, the victims could at least hope for that the report would open the doors for achieving justice and obtaining reparation. It is important to have in mind that truth commissions are as effective as governments are prepared to make them, but the STC report did not seem to encourage the Salvadoran judicial authorities to undertake investigations, even where responsible individuals had been named. The STC recognised the moral imperative of punishment but at the same time it recognised that there existed a number of probably insuperable difficulties within the Salvadoran judiciary, which prevailed at the time of writing the report. The STC therefore recommended that overcoming the dismal system of administration of justice should be a primary objective for the Salvadoran society. In addition, it did not take a strong line against the possibilities of a new amnesty law being passed. As soon as the STC's report had been published, the Salvadoran government politicised the report by issuing a broad amnesty law protecting those guilty of human rights violations. The government also completely ignored the STC's proposals for compensating the victims. Because of this, the STC's report can be criticised for not putting more emphasis on the Salvadoran state's obligations according to international law. In failing to do so, it was easier for the Salvadoran authorities to avoid its obligations. It is important to have in mind that a truth commission can not be a substitute for the state's obligation to investigate violations within its territory, identify and punish those responsible and repair the victims' sufferings.

However, as written above, to a large part it was up to the Salvadoran government to comply with the recommendations of the STC's report, in order to make it successful. The government did obviously not find itself obliged to follow the recommendations of the STC, even though they had agreed to do so when they signed the Peace Accords. Instead a new, broader and unconditional amnesty law was hastily passed in the name of national reconciliation. This law and the politics of negation uphold the impunity which hinders the victims from having independent investigations of their cases, achieving justice and obtaining reparation through the Salvadoran judicial system.

The reason for holding on to the politics of "forgiving and forgetting" is that the Salvadoran state itself, or an arm of the state, the military, has committed or encouraged the vast majority of violations. It stands quite clear that the Salvadoran government does not recognise the victims and their right to reparation because of fear that this could lead to demands of prosecuting those who so far have been effectively protected by the mechanisms of impunity. This is probably the main reason why the victims are being denied reparation - the fear of the consequences of recognising the victims and their rights according to standards of international law. This fear is also most likely the reason why the Salvadoran government has not even established a compensation fund, created a national monument in remembrance of the victims or given a public apology, according to the recommendations of the STC. The government has decided that "forgiving 
and forgetting" is the best option for everyone in order to reach national reconciliation, but the question is reconciliation for whom? The families which still have one or more children disappeared can not just forget and go on with their lives as if these children had never existed.

The politics of negation has also had strong affects on the Salvadoran judiciary. As the STC pointed out, the administration of justice did not work independent from the executive and still it has not dared to challenge the prevailing impunity for past human rights violations. The Supreme Court's decision to abdicate from its power to rule out the amnesty law as unconstitutional, claiming that this law is an entirely political act, speaks for itself. In its last decision in 2000 the Supreme Court considered the question of constitutionality and found that the law was not unconstitutional per se and then exempted a period of time from the scope of the law. However, the Supreme Court made clear that judicial officials should make the decision whether or not to prosecute, which poses yet another obstacle for the victims to obtain reparation. From this the conclusion can be drawn that the system of justice does not function properly. The Salvadoran Supreme Court has not worked sufficiently independent from the executive power and this contributes to the fact that El Salvador has not complied with its international obligation to provide victims of human rights with an effective remedy. However, the decisions issued by the Supreme Court relating to writs of habeas corpus, filed by the families of disappeared children, have showed that there has been a change in attitude, since the Supreme Court in its last decision urged the Attorney General's Office to take measures concerning the whereabouts of the Contreras children. However, the passivity of the Attorney General indicates that there still are many obstacles to overcome before impartial investigations and justice finally can be done.

The state has some margin of appreciation when it comes to dealing with the matter of past human rights violations and how to remedy victims. It must however provide the victims with a remedy that is effective, which should include some form of truth, justice and reparation. Completely ignoring the victims and their rights, as the Salvadoran state has done, can never be consistent with international law. Obviously, the Salvadoran government does not respect its obligation according to international human rights law to provide victims with remedy and reparation. In its attempts to justify the broad amnesty law, which so clearly is contrary to international law and in particular the right to an effective remedy and judicial protection, the Salvadoran state has relied on article 6(5) of Protocol II of the Geneva Conventions. Unfortunately this provision has been misinterpreted by many governments wishing to "forgive and forget" the past human rights violations. This can thus be seen as reasons why El Salvador does not comply with international law: lack of respect for international law and also misinterpretation of it in order to justify the politics of negation.

The PDDH has at various occasions tried to influence the government to take on its responsibilities according to international law regarding the 
disappeared children. Even though the PDDH is a governmental institution it is hard to work against the strong powers that support the impunity. The major problem of the PDDH is that it lacks an effective follow-up mechanism to ensure that its recommendations really are being implemented. Therefore, when it comes to issues concerning impunity for past human rights violations, the Salvadoran institutions and authorities, to which recommendations are directed, rarely complies with these. Probably, the work of the PDDH is more effective when it comes to human rights violations in present time, since it is not as politicised. In any case, the work of the PDDH concerning the disappeared children is important for the victims in the sense that it at least is trying to bring on a change in the prevailing impunity. It means that the suffering of the victims is recognised and no longer ignored, as was the case in the report of the STC.

\subsection{Will the victims obtain truth, justice and reparation?}

Recently, the judgment on the merits of the first Salvadoran case before the Inter-American Court of Human Rights was issued and hopes are high in the Salvadoran civil society that the impunity that has prevailed so far will get weaker. For the victims of human rights violations the Serrano Cruz case could mean that the state will begin to realise that it has responsibilities towards the victims. This judgment could put some pressure on the Salvadoran state to act in accordance with international law. Unfortunately the Inter-American Court did not have competence rationae temporis to deal with the question whether El Salvador was responsible for the enforced disappearance of the Serrano Cruz sisters. A judgment on this matter could have worked as an even stronger pressure on the Salvadoran state to take on its responsibilities.

However, there are strong indications that the Salvadoran state will not take much influence of the judgment of the Inter-American Court. First of all, it is rather worrying that the Salvadoran state party has tried to prove the nonexistence of the Serrano Cruz sisters at its audience at the Court. The way witnesses in the case have been treated by the Salvadoran authorities is also appalling. That the Salvadoran state would go from totally ignoring the victims and claiming that they are lying about their disappeared children to recognising the rights of the victims seems very unlikely. Secondly, this is the first Salvadoran case which has been accepted by the Inter-American Court and usually it takes more than one case to make a state take on its responsibilities according to international law. Thirdly, the fact that the Salvadoran government has not even acknowledged that children were abducted as a consequence of the government's counter-insurgency warfare is another obstacle for the prospect to achieve justice, obtain truth and reparation. As long as the state refuses to take on any responsibility for the disappearance of children, the victims will not be afforded reparation and impunity will remain strong. 
Above all the victims want the truth and serious investigations into the disappearances and that some measures of moral and material reparation are taken, such as an official apology and a reparation fund. They do not even talk about bringing those responsible to justice, even though this is one of the state's obligations according to international law. As written in the previous section, the Salvadoran state is not ready to comply with these demands, since doing that would recognise the rights of the victims, which could lead to further demands of bringing responsible individuals before justice. In the view of the government, national reconciliation means that the offenders of human rights law should be afforded protection from being prosecuted and that the victims should "forgive and forget". The Salvadoran state has not taken into account that every reconciliation must start with an apology and then move on from there. There are no indications that the president Tony Saca, who was elected 2004, views the matter differently than his predecessors, so a change in the attitude of the government seems far away.

Lately the focus has been put on the creation of a Search Commission. For the victims the creation of an independent and credible CNB would be the best thing that could happen right now, since truth is what they most of all want. Pro-Búsqueda has dedicated much of its work on lobbying for a CNB and still it has not given up hope on the formation of a functioning CNB. The creation of an Inter-institutional Search Commission on behalf of the Salvadoran government seems to be a step in the right direction when it comes to providing the victims with the truth about the disappearance of children. But looking more closely at the structure of this Commission, it will probably not function effectively since the civil society is not included in it. In addition to this, the reason for creating the Inter-institutional Commission is ambiguous. It was most likely not created with a genuine wish to provide the victims with the truth, but because of the Serrano Cruz case, which is before the Inter-American Court. In conclusion, all this put together shows that the human rights movement's demands for truth, justice and reparation on the national level have so far not won over the government's politics of negation and impunity, which remain strong. However, the civil society does not seem to give up hope and it has gotten new strength from the Serrano Cruz case. The persistent efforts of the civil society, in combination with international pressure on the Salvadoran state, will hopefully weaken the prevailing impunity, so that the victims finally can obtain truth, justice and reparation.

\subsection{Conclusions}

According to international human rights law El Salvador has the obligation to guarantee human rights and provide victims with effective remedies when violations have occurred. These obligations apply in cases where children have been abducted by government forces, as well as in cases where the FMLN has been involved. The obligations lead to certain duties, namely providing victims with truth, justice and reparation. When determining what 
constitutes adequate reparation, the principle of proportionality is of significance. The true identity should be legally established, if the found person wishes to. Compensation should be afforded to abducted children and their families for mental harm. Because of the gravity of the violation and the suffering caused to the victims, measures of rehabilitation and satisfaction should be taken.

It is clear that El Salvador is in breach of its international obligations to provide the victims of the enforced disappearance of children with truth, justice and reparation on the national level. This breach can lead to that El Salvador is held internationally responsible. In this case it is the InterAmerican Court that can judge on the question of state responsibility and that is what the Court has done in the Serrano Cruz case. However, such a judgment does not have direct implications for the victims at the national level, except for putting pressure on the state to comply with international law.

It can be concluded that the report of the STC did not put enough pressure on the Salvadoran state to provide victims with truth, justice and reparation in accordance with international law. However, the recommendations of the STC are as effective as the government is prepared to make them and in this case the politics of negation and the broad and unconditional amnesty law uphold the impunity, which work to the detriment of the victims. The main reason why the victims are being denied reparation is probably the fear of the consequences of recognising the victims and their rights according to standards of international law. Therefore the government claims that the best thing in order to reach national reconciliation is to "forgive and forget". Misinterpretations of and lack of respect for international law in order to justify the politics of negation can be seen as reasons why El Salvador does not comply with international law. In addition, the administration of justice has not been working independently from the executive and still it has not dared to challenge the prevailing impunity for past human rights. The only government institution which tries to bring on a change in the prevailing impunity for past human rights violations is the $\mathrm{PDDH}$, but since it lacks effective follow-up mechanisms, the Salvadoran institutions and authorities rarely complies with the recommendations.

The Serrano Cruz case could put some pressure on the Salvadoran state to act in accordance with international law, but there are strong indications that the Salvadoran state will not take much influence of the judgment. A change in the government's attitude regarding the politics of negation seems far away and as long as the state refuses to take on any responsibility for the disappearances of children, it will be difficult for the victims to be afforded reparation and impunity will remain strong. The Inter-institutional Commission created by the government will probably not function effectively; it was not created with a genuine wish to provide the victims with the truth. In conclusion, all this put together shows that the human rights movement's demands for truth, justice and reparation on the national level have so far not won over the government's politics of negation and 
impunity, which remain strong. However, if the efforts of the civil society and the international community to bring on a change persist, it could lead to that the rights of the victims will be recognised by the Salvadoran state. 


\section{Supplement A}

Maps of Central America and El Salvador. ${ }^{176}$

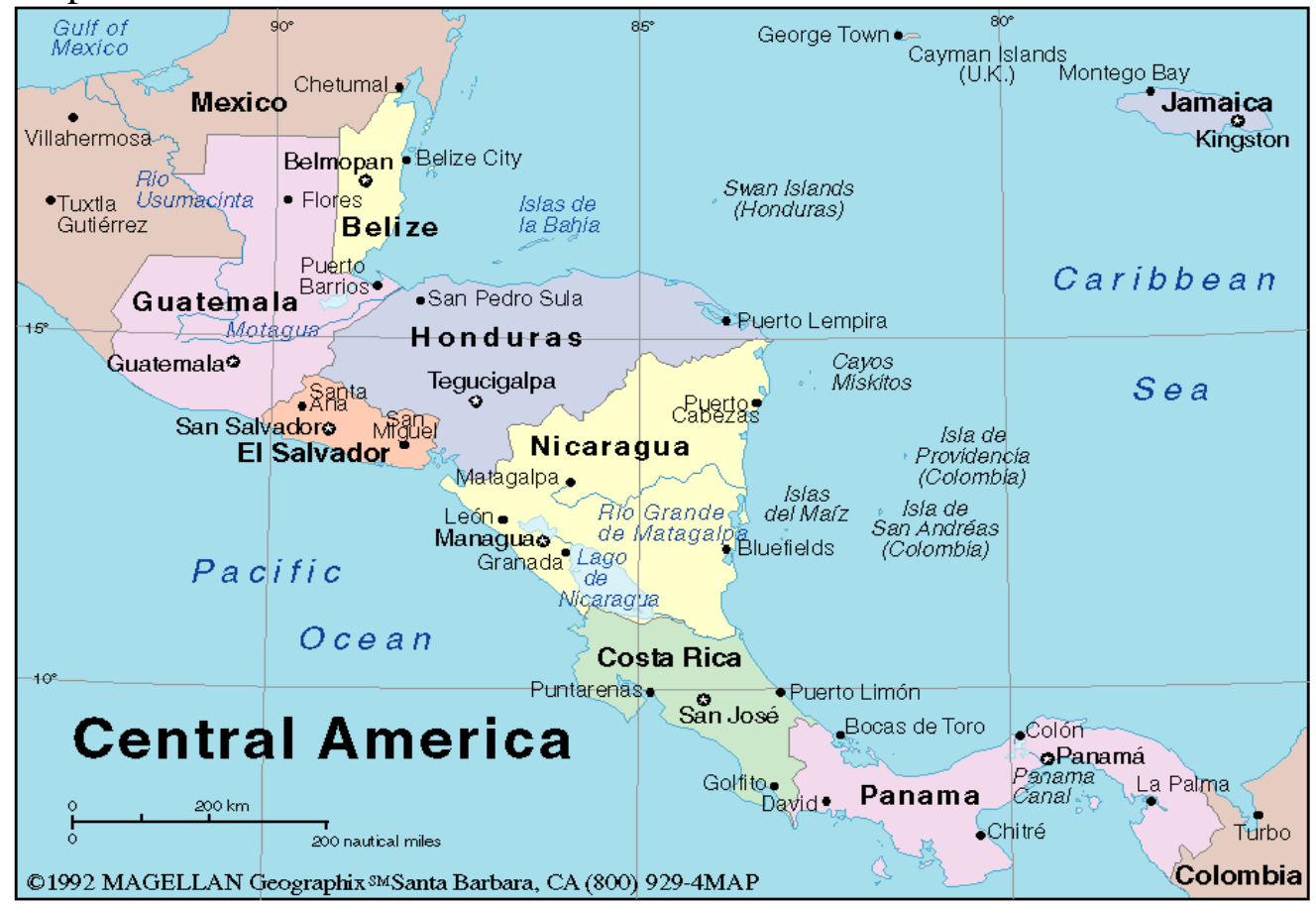

\footnotetext{
${ }^{176}$ Map of El Salvador with the different “departementos”, http://209.15.138.224 /inmoguanaco/m elsalvador, 2005-02-14 and Map of Central America, http://www.reliefweb.int/mapc/amer_cac/reg/ centam.html, 2005-03-31
} 


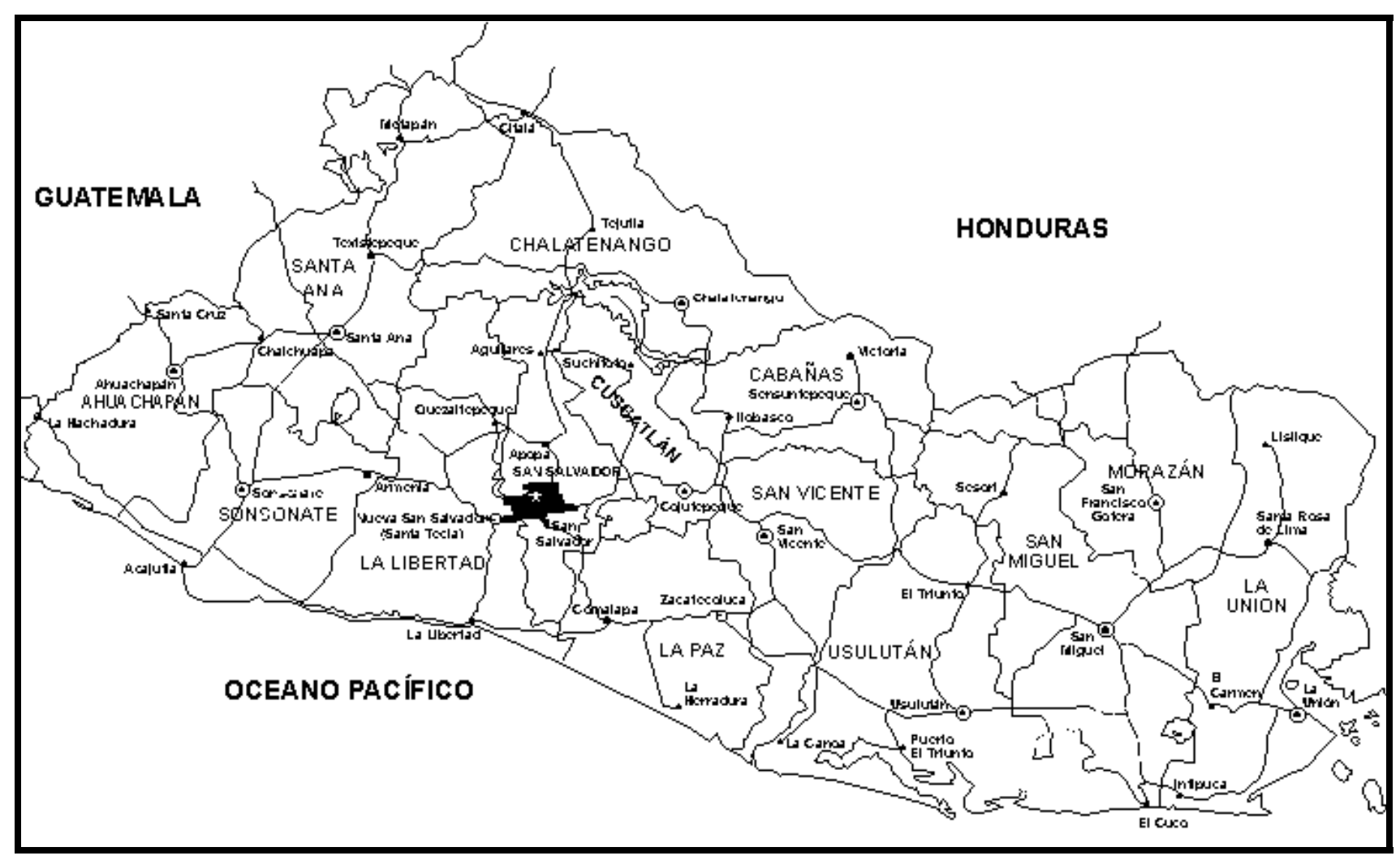




\section{Supplement B}

\section{Article 2(1) of the ICCPR}

Each State Party to the present Covenant undertakes to respect and to ensure to all individuals within its territory and subject to its jurisdiction the rights recognized in the present Covenant, without distinction of any kind, such as race, colour, sex, language, religion, political or other opinion, national or social origin, property, birth or other status.

\section{Article 2(3) of the ICCPR}

Each State Party to the present Covenant undertakes:

a. to ensure that any person whose rights or freedoms as herein recognized are violated shall have an effective remedy, notwithstanding that the violation has been committed by persons acting in an official capacity;

b. to ensure that any person claiming such a remedy shall have his right thereto determined by competent judicial, administrative or legislative authorities, or by any other competent authority provided for by the legal system of the State, and to develop the possibilities of judicial remedy;

c. to ensure that the competent authorities shall enforce such remedy when granted.

\section{Article 1(1) of the ACHR - Obligation to Respect Rights}

The States Parties to this Convention undertake to respect the rights and freedoms recognized herein and to ensure to all persons subject to their jurisdiction the free and full exercise of those rights and freedoms, without any discrimination for reasons of race, color, sex, language, religion, political or other opinion, national or social origin, economic status, birth, or any other social condition.

\section{Article 25 of the ACHR - Right to Judicial Protection}

1. Everyone has the right to simple and prompt recourse, or any other effective recourse, to a competent court or tribunal for protection against acts that violate his fundamental rights recognized by the constitution or laws of the state concerned or by this Convention, even though such violation may have been committed by persons acting in the course of their official duties.

2. The States Parties undertake:

a. to ensure that any person claiming such remedy shall have his rights determined by the competent authority provided for by the legal system of the state;

b. to develop the possibilities of judicial remedy; and

c. to ensure that the competent authorities shall enforce such remedies when granted. 


\section{Bibliography}

Bar-Yaacov, Nomi, 'The Role of Human Rights in Conflict Resolution in El Salvador and Haiti', Fletcher Forum World Affairs, 1995, vol. 19, pp. 51-63

Bassiouni, Cherif M., 'Accountability for Violations of International Humanitarian Law and Other Serious Violations of Human Rights', Post-conflict Justice, ed. Bassiouni, 2002, Transantional Publishers: Ardsley N.Y., pp. 3-54

Bassiouni, Cherif M., 'Proposed Guiding Principles for Combating Impunity for International Crimes', Post-conflict Justice, ed. Bassiouni, 2002, Transantional Publishers: Ardsley N.Y., pp. 255-282

Bassiouni, Cherif M., The Right to Restitution, Compensation and Rehabilitation for the Victims of Gross Violations of Human Rights and Fundamental Freedoms, Final report of the Special Rapporteur, 18 January 2000, E/CN.4/2000/62

Boven, Theo van, Study Concerning the Right to Restitution, Compensation and Rehabilitation for Victims of Gross Violations of Human Rights and Fundamental Freedoms, Final Report of the Special Rapporteur, 2 July 1993, E/CN.4/SUB.2/1993/8

Buergenthal, Thomas, 'The UN Truth Commission in El Salvador', Vanderbilt Journal of Transnational Law, 1994, vol. 27, issue 3, pp. 497-525

Call, Charles T., 'Democratisation, War and State-Building: Constructing the Rule of Law in El Salvador', Journal of Latin American Studies, 2003, vol. 35, issue 04, Cambridge University Press, pp. 827-862

Kaye, Mike, 'The Role of Truth Commissions in the Search for Justice, Reconciliation and Democratisation: the Salvadorean and Honduran Cases', Journal of Latin American Studies, 1997, vol. 29, issue 03, Cambridge University Press, pp. 693-716

Nowak, Manfred, Civil and Political Rights, including questions of: Disappearances and Summary Executions, Final report of the independent expert, 8 January 2002, E/CN.4/2002/71

Nowak, Manfred, Introduction to the Human Rights Regime, 2003, Martinus Nijhoff: Leiden, Boston

Orentlicher, Diane, 'Settling Accounts: The Duty to Prosecute Human Rights Violations of a Prior Regime’, Yale Law Journal, 1991, vol. 100, pp. 2537-2615

O'Shea, Andreas, Amnesty for Crime in International Law and Practice, 2002, Kluwer International Law: The Hague

Pisillo-Mazzeschi, 'International Obligations to Provide for Reparation Claims?', State Responsibility and the Individual: reparation in instances of grave violations of human rights, 1999, ed. Randelzhofer and Tomuschat, Kluwer Law International: The Hague

Popkin, Margaret, Peace without Justice: obstacles to building the rule of law in El Salvador, 2000, Pennsylvania State University Press 
Roht-Arriaza, Naomi and Gibson, Lauren, 'The Developing Jurisprudence on Amnesty', Human Rights Quarterly, vol. 4, issue 4, 1998, pp. 843885

Sharf, Michael, 'The Letter of the Law: the Scope of the International Legal Obligation to Prosecute Human Rights Crimes', Law and Contemporary Problems, vol. 59, issue 4, 1996, pp. 41-61

Shaw, Malcolm, International Law, 1997, Cambridge University Press: Cambridge

Whitfield, Teresa, 'Staying the Course in El Salvador', Honoring Human Rights, ed. Henkin, Alice H., 2000, Kluwer Law International: The Hague, pp. 319-341

Reports, resolutions, advisory opinions, national laws etc.

Agotamiento de los Recursos Internos como Requisito para Accesar al Sistema Interamericano de Protección de los Derechos Humanos. Caso Serrano Cruz, Asociación Pro-Búsqueda

Amnesty International Report, Where are the "disappeared" children?, 30 July 2003, AI INDEX: AMR 29/004/2003

Comunicado de Prensa de Pro-Búsqueda: Audiencia ante la Corte InterAmericana, 7-8 Septiembre 2004

Concluding Observations of the HRC: El Salvador, CCPR/CO/78/SLV, 22 August 2003

El caso de las hermanas Serrano Cruz: Una luz de esperanza para cientos de niños y niñas desaparecidas en el conflict armado de El Salvador, CEJIL, Primer Congreso Internacional sobre Derechos Humanos "Herbert Anaya Sanabria”, San Salvador 25-26 October 2004

El día más esperado, Asociación Pro-Búsqeda de Niñas y Niños Desaparecidos, 2001, UCA Editores: San Salvador

En Búsqueda, Identidad - Justicia - Memoria, publication of Pro-Búsqueda, época 2, vol. 9, August 2004, San Salvador

En Búsqueda, Identidad - Justicia - Memoria, publication of Pro-Búsqueda, época 2, vol. 6, September 2003, San Salvador

En Búsqueda, Identidad - Justicia - Memoria, publication of Pro-Búsqueda, época 2, vol. 3, October 2002, San Salvador

General Assembly Resolution 35/192, 15 December 1980

General Assembly Resolution 49/193, 23 December 1994

HRC General Comment 6/16 on the right to life, 27 July 1982

HRC General Comment 20/44 on article 7, Adopted at the Committee's forty-fourth session, 3 April 1992

Human Rights Watch: El Salvador's decade of terror, 1991

IACHR Resolution No. 1/03, On Trial for International Crimes, 24 October 2003

Inter-American Court of Human Rights, Advisory Opinion, OC-2/82, Series A, Judgements and Opinions, 24 September 1982

Inter-American Court of Human Rights, Advisory Opinion OC-9/87, Judicial Guarantees in States of Emergency (Arts. 27.2, 25 and 8 ACHR), Series A, Judgments and Opinions, 6 October 1987 
La Paz en Construcción - Un Estudio sobre la Problemática de la Niñez Desaparecida por el Conflicto Armado en El Salvador, Asociación ProBúsqueda, Enero 2003, San Salvador

Ley de la Procuraduría para la Defensa de los Derechos Humanos, decreto no. 183, Diario Oficial no. 45, Tomo no. 314, 20 February 1992

Ley de Amnistía General para la Consolidación de la Paz, decreto no. 486, Diario Oficial no. 56, Tomo no. 318, 20 March 1993

Ley de Amnistía, decreto no. 805, Diario Oficial no. 199, Tomo no. 297, 27 October 1987

Ley de Reconciliación Nacional, decreto no. 147, Diario Oficial no. 14, Tomo no. 314, 23 January 1992

Ley de una Comisión Inter-institucional, Decreto no. 45, Diario Oficial, Tomo No. 365, No. 185, 6 October 2004

PDDH resolution about the issue of disappeared children, case SS-0449-96, 30 March 1998

PDDH follow up resolution on case SS-0449-96, 10 February 2003

PDDH report about the Serrano Cruz case, final version, 2 September 2004

Plan Estratégico de Pro-Búsqueda 1998-2000

Seminario Regional "Víctimas y Justicia”, El Instituto de Derechos Humanos de la Universidad Centroamericana "José Simeón Cañas", 12 November 2004

The United Nations and El Salvador, United Nations Blue Book Series, Volume IV, 1995, Department of Public Information: New York

The UN Truth Commission Report: From Madness to Hope, published 15 March 1995

The Working Group on Enforced or Involuntary Disappearances, Civil and Political Rights, including the questions of Disappearances and Summary Executions, 21 January 2004, E/CN.4/2004/58

UN Declaration on the Protection of All Persons from Enforced Disappearance, A/RES/47/133, 18 December 1992

UN Press release: HRC considers civil and political situation in El Salvador, HRC $78^{\text {th }}$ Session, 23 July 2003

\section{International treaties and drafts}

American Convention on Human Rights, 1978

International Covenant on Civil and Political Rights, 1966

Inter-American Convention on the Forced Disappearance of Persons, 1994

Draft International Convention on the Protection of all Persons from Forced Disappearance, 1998

\section{Internet}

Political history of El Salvador from 2000 BC until today, http://wrc.lingnet.org/elsalhis.htm, 2004-09-09

Public hearing at the Committee of Foreign Affairs, Security and Defence Policy, Subcommittee on Human Rights, Brussels 30-31 October 1996, Impunity in Latin America by Luis Carlos Nieto, http://www.europarl.eu.int/hearings/impunity/latinam3_en.htm, 200409-10 
History and politics of El Salvador, http://www.nationmaster.com/ encyclopedia/El-Salvador, 2004-09-20

Report of election observers, http://www.nonviolentways.org/elsal032004.html, 2004-09-20

Articles about the disappeared children in an internet newspaper, http://www.elfaro.net/Secciones/Especiales/Desaparecidos/Desapareci dos4_20030707.asp and http://www.elfaro.net/Secciones/Especiales /Desaparecidos/ Desaparecidos3_20030707.asp, 2004-10-12

Information about the presidentelection 2004, http://www.elecciones2004. com.sv/NewsDetail.asp?ID=150, 2004-08-31

Article in the newspaper La Prensa Grafica, http://archive.laprensa.com.sv/ 20041104/nacion/36715b.asp, 2005-02-02

Article concerning the legality of amnesty laws: Argentina: legal memorandum on the Full Stop and the Due Obedience Laws submitted by Amnesty International and the International Commission of Jurists, 26 February 2004, http://www.icj.org/news.php3?id_article=3246\& lang=en, 2005-03-15

Map of El Salvador with the different "departementos", http://209.15.138.224/inmoguanaco/m_elsalvador, 2005-02-14

Map of Central America, http://www.reliefweb.int/mapc/amer_cac/reg/ centam.html, 2005-03-31

\section{Interviews}

Ardón, Veronica, lawyer at Asociación Pro-Búsqueda, 2004-11-17

Bernal Chévez, Efrén Arnoldo, Member of the Parliament (Asamblea Legislativa), representing FMLN, President of the Committee of Justice and Human Rights, 2004-11-10, 2004-11-11

Chavarría, Engracia, CPDH, 2004-12-15

Cruz, Pedro, lawyer at IDHUCA, 2005-01-15

León de, Gisela, lawyer at Cejil, San José, Costa Rica, written interview through e-mail, 2005-02-01

Mejía Delgado, Guadalupe, director of CODEFAM, “Asociación Comité de Familiares de Víctimas de Violaciones a los Derechos Humanos Marianella García Villas”, 2004-12-02

Mejía Trabanino, José Roberto, director of the Department of Human Rights, the Salvadoran Ministry of Foreign Affairs, 2004-11-11

Meléndez, Florentin, Salvadoran member of the IACHR, telephone call, 2004-12-04

Montenegro, Miguel Rogel, director of CDHES, “Comisión de Derechos Humanos de El Salvador", 2004-12-09

Salazar Flores, Luis Enrique, la Procuraduría para la Defensa de los Derechos Humanos, Procurador Adjunto de la Niñez y la Juventud, 2004-11-24 


\section{Table of Cases}

\section{Inter-American Court of Human Rights}

Blake v. Guatemala, judgment of 24 January 1998, ser. C no. 36

Garrido and Baigorria v. Argentina, judgment of 27 August 1998 on compensatory damages, ser. C no. 39

Serrano Cruz v. El Salvador, judgment of 23 November 2004 on preliminary objections, ser. C no. 118

Serrano Cruz v. El Salvador, judgment of 1 March 2005, ser. C no. 120

Velásquez Rodríguez v. Honduras, judgment of 29 July 1988, ser. C no. 4

Velásquez Rodríguez v. Honduras, judgment of 21 July 1989 on compensatory damages, ser. $\mathrm{C}$ no. 7

Villigrán Morales v. Guatemala, judgment of 19 November 1999, ser. C no. 63

\section{Inter-American Commission of Human Rights}

Chumbivilcas v. Peru, Report No. 1/96, 1 March 1996

Consuelo et al. v. Argentina, Report no. 28/92, 2 October 1992

Ignacio Ellacuría S.J and others v. El Salvador, Report No. 136/99, 22

December 1999

Lucio Parada v. El Salvador, Report no. 1/99, 27 January 1999

Masacre Las Hojas v. El Salvador, Report no. 26/92, 24 September 1992

Serrano Cruz v. El Salvador, Report no. 31/01, 23 February 2001

\section{Human Rights Committee}

Bautista v. Colombia, no. 563/1993, final views of 13 November 1995

Bleier v. Uruguay, no. 30/1978, final views of 29 March 1982

Laureano v. Peru, no. 540/1993, final views of 16 April 1996

Quinteros v. Uruguay, no. 107/1981, final views of 21 July 1983

Rodríguez v. Uruguay, no. 322/1988, final views of 9 August 1994

Vicario v. Argentina, no. 400/1990, final views of 27 April 1995 